\title{
Application of an ice sheet model to evaluate PMIP3 LGM climatologies over the North American ice sheets
}

Jay R. Alder ${ }^{1}$, Steven W. Hostetler ${ }^{1}$

${ }^{1}$ US Geological Survey, 104 CEOAS Admin Building, Corvallis, 97331, USA

5 Correspondence to: Jay R. Alder (jalder@usgs.gov)

Abstract. We apply the Community Ice Sheet Model (CISM2) to the Palaeoclimate Modelling Intercomparison 3 (PMIP3) Last Glacial Maximum (LGM) simulations to determine if the general circulation models (GCMs) simulated surface temperature and precipitation climatologies would support the large North American ice sheets. We force CISM2 with eight PMIP3 GCMs, and an additional model,

10 GENMOM. The ice sheet simulations indicate seven GCMs produce LGM temperature and precipitation climatologies that support positive mass balances of the Laurentide and Cordilleran ice sheets (LIS, CIS) in areas corresponding to those prescribed in the GCMs, and two GCMs simulate July temperatures that are too warm to support the ice sheets. Four of the nine GCMs support the development of ice sheets in Beringia in the CISM2, in conflict with the driving GCM and reconstructions that indicate the area was

15 ice-free. We test the sensitivity of our results over a range of snow and ice positive degree-day factors, and we evaluate the role of albedo, and shortwave and longwave radiation in the simulations. Areas with perineal snow in the GCM simulations are found to correspond well to the CISM2 simulation of ice presence.

\section{Introduction}

The Palaeoclimate Modelling Intercomparison 3 (PMIP3) Last Glacial Maximum (LGM, 21,000 years ago) experiment, which is part of the Coupled Model Intercomparison Project Phase 5 (CMIP5, Taylor et al., 2012), provides an opportunity to evaluate the ability of general circulation models (GCMs) to simulate climate states different from the present. (Braconnot et al., 2012; Hargreaves et al., 2013; Harrison et al., 2014). The extent, height, and topography of the North American ice sheets (NAIS) are 25 key boundary conditions for LGM model simulations that have been explored in numerous model 
experiments (Braconnot et al., 2007; COHMAP Members, 1988; Harrison et al., 2016; Schmittner et al., 2011). The three phases of PMIP have included different ice sheet reconstructions that vary greatly in volume and surface topography (Abe-Ouchi et al., 2015; Peltier, 1994; 2004). The area and southern extent of the North American ice sheets (NAIS) is well constrained (Dyke, 2004; Dyke and Prest, 1987;

5 Ehlers, 2011), yet there is little direct evidence of the distribution of the ice mass. Geophysical models are used to estimate the ice sheet surface topography constrained by observed relative sea-level changes and post-glacial rebound rates (Abe-Ouchi et al., 2015; Marshall et al., 2002; Peltier et al., 2015). While the LGM climate is reasonably well constrained by data over land and oceans, climate model simulations are the only source of information for precipitation, temperature, and radiative balance over ice sheets

10 which control surface mass balance and hence ice mass and topography. The use of ice sheet configurations as boundary conditions and the resulting climate simulations in the PMIP3 project provide the opportunity to employ a stand-alone, dynamic ice sheet model to evaluate the climatologies over NAIS and the degree to which those climatologies support the area of the NAIS.

In a previous evaluation of the PMIP models, Pollard (2000) used output from 10 PMIP1 models

15 and found that four of the models produced positive mass balances over the Laurentide ice sheet (LIS), where the remaining six had unrealistically negative surface mass budgets. In a recent study, Ullman et al. (2015) applied a surface energy balance model to a LGM GCM simulation and found the LIS to have a positive mass balance in the interior of the ice sheet and strongly negative mass balance along the margins, resulting in a net positive budget. Here we evaluate the ice-sheet climatologies of eight PMIP3

20 models and one additional model by using the simulated temperature and precipitation fields to force a 3$\mathrm{D}$ thermomechanical ice sheet model to simulate the absence or presence of simulated ice relative to the fixed ice sheets prescribed in the GCMs. Our goal is to use the ice sheet model to determine if the simulated temperature and precipitation climatologies support the NAIS.

The paper is organized as follows: Section 2 describes the ice sheet model, initialization and 25 PMIP3 driving climatology; Section 3 reviews results of the ice sheet model simulations; Section 4 analyzes GCM scale snow, albedo and radiation fields to put the ice sheet simulations into the context of the larger GCM simulation; Section 5 concludes with a summary of our results and implications for future CMIP assessments. 


\section{Methods}

\subsection{Ice sheet model and configuration}

We apply the 3-D thermomechanical Community Ice Sheet Model 2.0.5 (CISM, Price et al., 2015; Rutt et al., 2009). We drive CISM2 with nine PMIP3 GCMs through a one-way, offline, coupling. CISM2

5 is configured to use a shallow-ice approximation and annual positive degree-day (PDD) mass balance scheme (Reeh, 1991) such that surface melt is proportional to the sum of positive degree-days over a year. The model has been successfully applied to simulate the Greenland Ice Sheet (Lipscomb et al., 2013; Lunt et al., 2008; Stone et al., 2010) and the North American deglaciation (21 - 7ka) (Gregoire et al., 2012; 2015). In this application, we use monthly temperature and precipitation from the PMIP3 GCMs in the

10 annual PDD scheme. Daily air temperatures in the PDD scheme are assumed to follow a sinusoidal cycle based on mean-annual and July temperatures (Price et al., 2015). In the PDD scheme, the calculation of melt is sensitive to July temperature, as it defines the number of days above freezing (Reeh, 1991). All precipitation is assumed to fall as snow, and up to $60 \%$ of the snow melt can refreeze.

Our model configuration largely follows that of Gregoire et al. (2012) who used the same 40-km

15 North American domain on a Lambert azimuthal equal area projection with a soft bed basal sliding parameterization for sediment (Table 1). The domain encompasses the LIS, Cordilleran Ice Sheet (CIS) and Greenland Ice Sheet. Gregoire et al. (2012) used PDD factors of $3 \mathrm{~mm} \mathrm{~d}^{-1}{ }^{\circ} \mathrm{C}^{-1}$ for snow and $8 \mathrm{~mm} \mathrm{~d}$ ${ }^{1}{ }^{\circ} \mathrm{C}^{-1}$ for ice (Marshall et al., 2002); however, these values are often derived from modern-day Greenland observations and are not well constrained for the LIS (Pollard, 2000), and Hebeler et al. (2008), for

20 example, found that the simulated ice extent of the Fennoscandian Ice Sheet to be sensitive to the choice of PDD factors. To address uncertainties in PDD factors, we explore the sensitivity of the NAIS simulations to a range of PDD factors in 12 combinations of $[3,4,5] \mathrm{mm} \mathrm{d}^{-1}{ }^{\circ} \mathrm{C}^{-1}$ for snow and $[8,12,16$, $20] \mathrm{mm} \mathrm{d}^{-1}{ }^{\circ} \mathrm{C}^{-1}$ for ice (range suggested by Stone et al., 2010), resulting in a total of 108 simulations for all the GCMs. A constant lapse rate of $5{ }^{\circ} \mathrm{C} \mathrm{km}^{-1}$ (Abe-Ouchi et al., 2007; Gregoire et al., 2012) is used

25 to adjust temperature between the GCM topography and CISM2 surface height.

The large volume of the NAIS complicates initializing CISM2 to LGM conditions. One approach is to spin-up the model with modern topography and build up ice through the last glacial-interglacial cycle using a climate-index technique (Charbit et al., 2007; Gregoire et al., 2012; Marshall and Clarke, 
1999; Marshall et al., 2002; Zweck and Huybrechts, 2005). A second approach is to use modern topography with a eustatic sea level adjustment, which is subject to large lapse corrections. We opted for a third alternative: to initialize CISM2 with a surface height similar to the GCM LGM topography, which minimizes lapse adjustments. The ICE-6G_C reconstruction (Argus et al., 2014; Peltier et al., 2015)

5 provides both ice thickness and orography at the LGM, which allowed us to initialize the NAIS in the CISM2 with reasonable ice volume, relative sea level changes and bedrock depression. We note that the blended CMIP5/PMIP3 ice sheet (Abe-Ouchi et al., 2015) has the same areal extent as ICE-6G_C over the NAIS, but different surface topography. The North American change in ice volume (LGM minus present), expressed in eustatic sea level equivalent (SLE), is $80.5 \mathrm{~m}$ for ICE-6G_C, which is greater than

10 the composite CMIP5/PMIP3 (78.6 m) and ICE-6Gv.2 (76.8 m), but within the range of other estimates (60.5 - $82.5 \mathrm{~m}$, Abe-Ouchi et al., 2015).

We integrated CISM2 for 5000 years to ensure that the ice sheets had sufficient time to respond to the GCM forcing. A simulation length of 5000 years is roughly equivalent to the duration of the LGM (7500 years, 26.5 to $19 \mathrm{ka}$ ) proposed by Clark et al. (2009) during which global ice sheets were in near-

15 equilibrium. Although the simulated ice volumes were not in true equilibrium after 5000 years, the areal extents were largely stable. If the GCM simulated temperatures are too warm in areas with prescribed ice cover, the ice sheet model will ablate until the initialization ice is removed, resulting in a data-model mismatch. If the GCM simulated temperatures are too cold in areas prescribed to be land in the GCM, the ice sheet model will incorrectly accumulate ice, also a data-model mismatch. Thus, evaluating the absence

20 or presence of ice cannot constrain lower temperatures over the NAIS but can constrain the upper bound of temperature on ice grid cells and lower bound of temperature on land grid cells.

\subsection{PMIP3 models and forcing climatology}

We evaluate LGM simulations from eight PMIP3 models from the CMIP5 archive and GENMOM (Alder et al., 2011) (Table 2). While not part of PMIP3, we included GENMOM in our evaluation because

25 the boundary conditions used in the LGM simulation are similar to those of PMIP3 (Alder and Hostetler, 2015) and earlier versions of the GENESIS atmospheric model were included in previous PMIP evaluations (Joussaume et al., 1999; Pinot et al., 1999; Pollard, 2000). 
We calculated long-term monthly climatological means from the available time series for each model over its respective grid. We use raw model output directly, without bias correcting the model output by an observed modern climatology (i.e. 'delta' method, Pollard, 2000). We drove CISM2 with the monthly values of near-surface air temperature (tas) and precipitation ( $p r)$. Our approach is 'one-way' in

5 that simulated changes of the ice sheet do not feedback to the driving fields through attendant changes in albedo, the energy balance, or circulation. Surface temperatures vary through a lapse correction that adjusts for differences between the fixed GCM topography (orog) and the dynamic ice sheet surface height simulated by CISM2. Where available, we also obtained additional GCM fields, such as land mask $(s f t l)$, ice mask (sftgif), snow area fraction (snc), snow depth (snd), surface shortwave, and longwave

10 fields (rsds, rsus, rlds, rlus) to broaden the analysis.

The expression of the ice sheet topography varies based on the resolution of the GCM: higher resolution models have a faithful implementation of the $1^{\circ} \times 1^{\circ}$ CMIP5/PMIP3 ice sheet (Fig. 1). Two GISS-E2-R simulations have been submitted to the PMIP3 archive: one that uses ICE-5G and a second one that blends ICE-5G with a different reconstruction of the LIS surface height (Licciardi et al., 1998).

15 To drive CISM2, we chose the blended Licciardi et al. (1998) and ICE-5G realization because that simulation is similar to the CMIP5/PMIP3 surface topography. Differences in the height of the two LIS configurations have been shown to drive changes in planetary wave structure and atmospheric circulation (Ullman et al., 2014) which result in different temperature and precipitation climatologies over the LIS. Unlike the CMIP5/PMIP3 ice sheet, the GISS-E2-R configuration has a clear divide of lower elevation

20 between the LIS and the CIS. The GENMOM simulation also uses Licciardi et al. (1998) for the LIS topography, but blended with ICE-4G elsewhere (Table 2). Initializing GENMOM and GISS-E2-R with ICE-6G_C rather than their respective ice sheet configurations does not alter the results.

The CNRM-CM5 and FGOALS-g2 model files have surface topographies that are inconsistent with their ice masks in that their masks indicate no ice over Hudson Bay. Their simulated climate fields appear to be reasonable, so the mask artifact may be a byproduct of the Coupled Model Output Rewriter (CMOR, http://www2-pcmdi.llnl.gov/cmor) postprocessor setting the ice mask to zero in grid cells that are ocean in the piControl experiment. The ice mask over the Fennoscandian Ice Sheet in both models supports this assessment. 


\section{Results}

\subsection{LGM climatology}

For all models the mean annual temperature (MAT) is below freezing in nearly all ice-covered grid cells, and many models simulate MATs below $-30{ }^{\circ} \mathrm{C}$ over the LIS (Fig. 2, top). CNRM-CM5

5 displays the weakest cooling and IPSL-CM5A-LR the strongest. CNRM-CM5 also has the weakest global land-based cooling of the PMIP3 models (Harrison et al., 2015). With the exception of CNRM-CM, most of the models simulate July temperatures over the LIS well below freezing (Fig. 2, bottom). MRI-CGCM3 displays above-freezing temperatures along the southern margin of the LIS, a feature that CCSM4 also exhibits to a lesser degree. Nearly half the models (CCSM4, FGOALS-g2, GISS-E2-R, MIROC-ESM)

10 simulate areas of below freezing July temperatures over Beringia. In the PDD melt calculation, July temperatures below freezing result in no annual melt.

All the models simulate similar mean-annual precipitation over NAIS (Fig. 3). CCSM4 and CNRM-CM5 display the wettest interiors and GISS-E2-R simulates substantial precipitation along the divide between the LIS and the CIS. Winters are dry in the interior and wet on the margins, particularly

15 along margins adjacent to the oceans. Precipitation penetrates further into the interior of the ice during summer, where precipitation totals are generally between $3-10$ times greater than winter (not shown). Most of the models maintain summer temperatures below freezing, making summer the strongest accumulation season with $40-60 \%$ of the annual total precipitation occurring between June and August.

\subsection{Summary of PDD factors}

A key issue underlying the simulations is establishing the sensitivity of steady-state ice sheets to the PDD factors. We chose to specify a set of values for snow and ice PDD factors in CISM2 that we used for all models. Most model simulations display relatively low sensitivity of the ice sheet extent to the PDD factors, with all 12 simulations for each GCM largely displaying the same ice sheet extent (Fig. 4). Ice mask differences between the suite of PDD factor simulations are limited to the margins. CCSM4,

25 GENMOM, and GISS-E2-R forced CISM2 simulations display southern boundaries that are well constrained by the GCM across all combinations of snow and ice factors. The CCSM4 and GISS-E2-R simulations display substantial ice over Beringia that is not specified as a boundary condition in the 
GCMs, and the GENMOM and GISS-E2-R simulations display ice extents greater than prescribed in the GCMs along much of their northern margins. The southern margins in the IPSL-CM5A-LR, MIROCESM, and MPI-ESM-P simulations extend further south than is prescribed in the respective GCMs. Many of the PDD combinations in the FGOALS-g2 simulations produce ice that extends almost to the bottom

5 of the model domain. The prescribed position of the southern margin varies somewhat among the GCMs due to their varying resolutions. The four of the seven models that simulate a reasonable LIS also simulate greater ice-covered area over Beringia.

When forced by CNRM-CM5 or MRI-CGCM3, the CISM2 failed to simulate the NAIS comparable to the GCM boundary conditions, for any combination of PDD factors. All the CISM2

10 simulations were initialized with ICE-6G_C volume and bedrock depression, but the initial ice volume is ablated in regions with negative mass balance in these two GCMs. Both models simulate July temperatures that are too warm to support the LGM ice. The MRI-CGCM3 simulations display a feedback wherein the negative mass balance along the southern margin reduces the elevation of the ice, which causes the surface temperature to warm through lapse rate correction as the difference between the GCM

15 surface topography and the increasingly lower CISM2 surface height is amplified, which in turn drives the MRI-CGCM3 southern margin further north.

Both ICE-6G_C and the blended CMIP5/PMIP3 ice sheet include mountain glaciers and ice caps over the US Rocky Mountains and the Sierra Nevada. A number of higher resolution GCMs prescribe this ice as boundary conditions which provide an additional target to assess if the simulated temperature 20 and precipitation climatologies of the GCMs support permanent ice at higher elevations south of the NAIS margin. Both IPSL-CM5A-LR and MPI-ESM-P CISM2 simulations produce ice in the Sierra Nevada where it is specified in the GCMs. The GENMOM and GISS-E2-R CISM2 simulations display ice in the US Rocky Mountains even though the glaciers are not prescribe in the GCMs. Areas in US Rocky Mountains that should have isolated mountain glaciers are connected to the LIS/CIS in the FGOALS-g2, 25 IPSL-CM5A-LR, and MIROC-ESM simulations with most combinations of PDD factors, indicating the GCM temperatures are too cold or precipitation is too high, or both, at these lower latitudes. 


\subsection{CISM2 simulated ice sheets}

Seven out of nine GCMs simulate temperature and precipitation that produce a reasonable extent of the LIS. In many cases, the simulated southern margin is in close agreement with the prescribed ice sheets in the GCMs. The ice margins simulated by CISM2 are in general steeper and the domes are lower

5 than ICE-6G_C. The CISM2 develops maximum ice sheet thicknesses $>2800 \mathrm{~m}$, which are $\sim 800 \mathrm{~m}$ lower than the ICE-6G_C that is $>3600 \mathrm{~m}$ in some regions (Fig. 5). After the first 100 years of CSIM2 simulation, the thickest areas initialized from ICE-6G_C begin to thin and flatten, indicating that either the CISM2 physics or our choice of parameters do not support the domes present in ICE-6G_C. The CISM2 includes a parameterization that scales ice advection. We conducted sensitivity tests with CISM2

10 to investigate whether the steep domes could be reduced by reducing the flow factor parameterization from 5 to 1 which effectively reduces the viscosity of the ice but we found that the margins and dome shapes were not sensitive to this parameter.

The GCMs that simulated below freezing July surface air temperatures over Beringia developed large ice volumes in this region after 5000 yrs. In a number of CISM2 simulations, the ice thickness 15 exceeds $2000 \mathrm{~m}$ which causes a corresponding bedrock depression. In the GENMOM CSIM2 simulations, a small area of positive mass balance develops over Beringia along the Arctic Ocean and the ice advects into adjacent grid cells with zero or slightly negative mass balance. The advected ice in these adjacent cells cools air temperatures through the lapse correction, which produces a net positive mass balance that is ultimately balanced by ablation thereby stabilizing the Beringian ice cover.

South-to-north cross section transects along the eastern portion of the ice sheet illustrate the steep margins simulated by CISM2 (Fig. 6). Most PMIP3 models produce ice sheets in CISM2 that are broadly similar in extent but lower than ICE-6G_C and the various combinations of PDD factors produce largely similar ice sheets. MRI-CGCM3 has the largest spread across the combinations of PDD factors, indicating the feedback driving the northward collapse from the southern margin, as described above, is sensitive to

25 the PDD factors. The steeper simulated southern margins result in total ice volumes that exceed that of ICE-6G_C. In most cases, the simulated bedrock depression is in good agreement with ICE-6G_C along the transect. The agreement in bedrock depression among the simulations and ICE-6G_C indicates the CISM2 is capturing the balance between mantel relaxation and the load of the ice sheets. Exceptions are 
FGOALS-g2 and MPI-ESM-P that place the southern margin at too low a latitude which depresses bedrock further south.

After 5000 simulated years, seven CISM2-GCM pairs perform well by simulating positive mass balance that largely aligns with the ice-covered areas prescribed in the GCMs. There is particularly good

5 agreement along the southern margins in the CCSM4, GENMOM, and GISS-E2-R CISM2 simulations (Fig. 7), which each produce mass balance equilibrium lines that correspond to the GCM ice-land boundary. In each of these simulations the ice sheet boundary extends slightly beyond that of the GCM, where the CISM2 simulated mass balance is strongly negative. July air temperatures in FGOALS-g2 and IPSL-CM5A-LR are $1-3{ }^{\circ} \mathrm{C}$ cooler than GENMOM or GISS-E2-R along southern margin of the CIS

10 (not shown), in agreement with Pollard (2000) that the mass balance along the margin is very sensitive to small temperature differences. The GCMs that simulated below freezing July temperatures in Beringia (CCSM4, FGOALS-g2, GISS-E2-R, MIROC-ESM) display expanded areas of positive mass balance as ice volume develops. The two GCMs that fail to produce the correct extent of the LIS in CISM2 (CNRMCM5 and MRI-CGCM3) have greatly reduced areas of positive mass balance relative to their GCM

15 prescribed ice sheet extent.

\subsection{Volume and sea level equivalent}

Our experimental design and use of fixed climatologies to drive CISM2 limits the degree to which the simulated total North American ice volumes are directly comparable to reconstructions, but it is useful to analyze total ice volume among models and PDD factors (Fig. 8). The CCSM4, GENMOM, GISS-E2-

$20 \mathrm{R}$, and IPSL-CM5A-LR driven simulations produce ice volumes that are in reasonable agreement (within $\pm 10 \%$ ) with ICE-6G_C over a range of PDD factors. Every GENMOM PDD simulation has NAIS volumes within $\pm 10 \%$ ICE-6G_C. All combinations of PDD factors yield ice volumes $>110 \%$ of ICE6G_C in the FGOALS-g2, MIROC-ESM and MPI-ESM-P based simulations. Simulations that produce NAIS changes in volume $>90 \mathrm{~m}$ of sea level equivalent (SLE) are likely unrealistically high given that

25 the CMIP5/PMIP3 estimated total global LGM SLE is $121.5 \mathrm{~m}$, which includes contributions from Eurasia and Antarctica (Abe-Ouchi et al., 2015). Since most of the CISM2-GCM combinations simulate the extent of the LIS reasonably well, the excess ice is attributed to the spurious simulation of ice in 
Clim. Past Discuss., https://doi.org/10.5194/cp-2017-102

Manuscript under review for journal Clim. Past

Discussion started: 21 August 2017

(c) Author(s) 2017. CC BY 4.0 License.

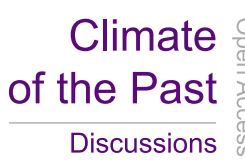

Beringia and steep idealized margins. No combination of PDD factors lead to ice volumes within $\pm 10 \%$ of ICE-6G_C in the CNRM-CM5 or MRI-CGCM3 simulations. The suite of PDD factors produce an average range of $4.3 \times 10^{6} \mathrm{~km}^{3}$ of ice volume from the seven GCMs that simulate a reasonably sized LIS with CISM2, indicating total ice volume is sensitive to the choice of PDD factors even though ice sheet

5 area largely is not.

The simulated CISM2 ice volumes did not reach steady state after 5000 years. The seven GCMs driving CISM2 that simulated the LIS area reasonably well continued to accumulate to unrealistically large volumes when the CISM2 was integrated for up to 50,000 model years. The ice volume values reported here are therefore sensitive to the time period of analysis. Our use of 5000 years was chosen as

10 the approximate time period when ice sheet area stabilizes in most simulations. Allowing the ice sheet volume to come to equilibrium is a function of CISM2 parameters such as the sliding scheme, basal traction coefficients, viscosity, and flow factor as opposed to local surface mass balance from the GCMs.

\section{Discussion}

\subsection{GCM snow cover and albedo}

The nine GCMs include different Land Surface Models (LSMs); although, CCSM4 and FGOALSg2 use different versions of the Community Land Model (see Table 9.A.1 in, Flato et al., 2013). The seasonal cycle of snow and albedo in the LGM simulations differ substantially among the LSMs. Regions with 'run away snow' occur over the ice sheet where summer melt is insufficient to offset snowfall so year-round snow continues to accumulate. The presence of deep snowpack alters the seasonality of

20 albedo, net radiation and the sensible and latent heat fluxes. To prevent the models from accumulating snow indefinitely, most GCMs impose a maximum limit on either snow depth or snow amount, which varies by model. For example, GENMOM limits snow depth to $10 \mathrm{~m}$, whereas CCSM4 limits snow amount to $1000 \mathrm{~kg} / \mathrm{m}^{2}$.

Most of the GCMs simulate year-round snow cover over substantial areas of the interior of the

25 LIS (Fig. 9). CNRM-CM5 is the exception due to its anomalously warm air temperature which results in lower fractional snow coverage in March, whereas all the other models maintain $\sim 100 \%$ fractional 
coverage. The GISS-E2-R March snow cover map indicates masking artifacts similar to CNRM-CM5, with snow depth set to zero in Hudson Bay, and in parts of Beringia (i.e. grid cells that are ocean in the piControl experiment). The regions with July snow cover correspond well to regions with positive mass balance in CISM2 (Fig. 7), including the presence of July snow cover in Beringia. Both CCSM4 and

5 MRI-CGCM3 display low July snow cover along the southern margin of the ice sheet, corresponding to above freezing temperatures.

The methods used to determine albedo in LSMs ranges from specified values that are spatially and temporally invariant to computations that account for variations in solar declination angle, snow age, snow optical properties, ice thickness, and the presence of surface melt ponds (Pollard, 2000). It is beyond

10 the scope of this paper to detail the albedo calculation in each GCM; however, some broad observations are insightful. The GCMs display a wide range of July albedo over NAIS (Fig. 10). The six GCMs that simulate the largest ice volumes in CISM2 also have high albedos corresponding to the ice-covered areas prescribed in the GCM. In the six GCMs, the July albedos are generally > 0.7 on the ice-covered grid cells. Half of these six models display spatially uniform albedos (IPSL-CM5A-LR, MIROC-ESM, MPI-

15 ESM-P), whereas albedo is spatially varying in the other half (CCSM4, GENMOM, GISS-E2-R). CNRMCM5 and MRI-CGCM3 display lower albedos than the other PMIP3 models, particularly in areas that are snow-free. The southern portion of the ice sheet in MRI-CGCM3, for example, has an albedo of $\sim 0.12$, a value twice that of seawater and half that of land cells. The low albedos on snow-free ice cells are possibly due to the LSMs approximating surface melt ponds, which are less reflective than either snow or ice. In

20 contrast, GENMOM has a simple representation of surface liquid and melt ponds such that visual waveband albedos linearly decrease between $-5{ }^{\circ} \mathrm{C}$ and $0{ }^{\circ} \mathrm{C}$ with minima of 0.6 for snow and 0.5 for ice (Pollard, 2000).

\subsection{Ice in Beringia}

Of the nine PMIP3 models, four support extensive areas of ice whereas the remaining five are

25 largely ice-free (Fig. 7). Adjacent pollen reconstructions for northern Alaska indicate a mixed response of warmer (cooler) and wetter (drier) LGM climate relative to present (Bartlein et al., 2011). Some PMIP2 models displayed warmer-than-present surface temperatures in Beringia due to altered circulation patterns 
driven by the height of the ICE-5G ice sheet (Otto-Bliesner et al., 2006). Although the ICE-6G ice sheet is significantly lower than ICE-5G, a number of PMIP3 models (CNRM-CM5, IPSL-CM5A-LR, MPIESM-P and MRI-CGCM3) simulate warmer-than-present summer temperatures in Beringia (See supplemental materials in Alder and Hostetler, 2015). As previously noted, the four PMIP3 models that

5 support extensive ice development in Beringia, regardless of choice of PDD factors (Fig. 7), are the models that simulate below freezing July temperatures (Fig. 2).

The simulated Beringian annual climatologies of temperature, precipitation, snow cover, albedo and radiation fields illustrate the inter-model differences that support ice in Beringia (Fig. 11). All of the PMIP3 models simulate winter temperature below $-25^{\circ} \mathrm{C}$, but the models that support ice are near or

10 below freezing during summer. The annual PDD calculation of melt is inherently sensitive to July temperatures near $0{ }^{\circ} \mathrm{C}$ because it does not fully resolve high frequency departures from the monthly mean (Reeh, 1991) and so cannot capture individual days above freezing that could drive melt. The GCMs display similar seasonal cycles of precipitation with relatively dry winters and wet summers. FGOALSg2 has the lowest annual precipitation ( $\left.271 \mathrm{~mm} \mathrm{yr}^{-1}\right)$, yet it still develops ice due to cold July temperature 15 and weak melting.

There are clear differences among the GCMs in the seasonal cycle of snow; three of the models that support ice in CISM2 are snow covered year-round. The GISS-E2-R snow cover (Fig. 11) displays the previously mentioned artifact where emergent land cells between LGM and present day are set to zero fractional snow cover, making the spatial average $\sim 63 \%$ snow cover year-round. The high flat albedo 20 seasonal cycle implies the model is simulating snow cover year-round despite the masking issues in the snow cover. The seasonality of albedo indicates the models that support ice in CISM2 also maintain higher albedos than the models that do not develop ice. (The IPSL-CM5A-LR model is missing snow area fraction (snc) files in the CMIP5 archive, but we infer from the albedo seasonality that the model is simulating lower snow cover during winter than the other PMIP3 models.) Due to the higher albedos, the models that support ice in CISM2 simulate much higher reflected shortwave radiation during summer. Both GENMOM and MPI-ESM-P have below average incident shortwave radiation due to absorption and reflection in the atmosphere, but net radiation in these models is compensated by higher-than-average downward longwave radiation which maintains above freezing air temperatures. 
Clim. Past Discuss., https://doi.org/10.5194/cp-2017-102

Manuscript under review for journal Clim. Past

Discussion started: 21 August 2017

(c) Author(s) 2017. CC BY 4.0 License.

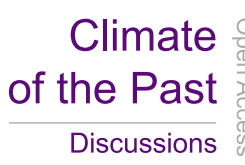

(c) (i)

\section{Conclusions}

Our application of CISM2 to simulate the NAIS provides an additional way to evaluate the temperature and precipitation climatologies of the PMIP3 models. Seven out of nine PMIP3 models support realistic ice in good agreement with the ice extent prescribed in the GCMs, a marked improvement over previous generations of PMIP models. The development of ice in these models indicates the simulated temperatures, particularly in July, are cool enough to result in a positive net surface mass balance. Our results suggest that the July snow cover simulated by the GCMs corresponds well to the locations where CISM2 simulates ice. Four models simulate a total ice volume within $\pm 10 \%$ the ICE6G_C reconstruction with some combination of PDD factors. Total NAIS volume is sensitive to snow

10 and ice PDD factors, but the ice sheet extent and location of ablation zones generally are not. The climatologies of four of the nine PMIP3 models produced positive mass balance in CSIM2 over Beringia, which is known to have been ice-free (Dyke, 2004). Analyses of GCM snow and albedo fields indicate these models maintain seasonal snow cover in Beringia longer than the other models. Enhanced atmospheric and surface dust is known to have is played a role in the radiative balance during the LGM,

15 but is not included in the PMIP3 models or in GENMOM. Asian dust sources may have darkened the surface albedo during the snow melt season, keeping Beringia ice-free (Bauer and Ganopolski, 2014; Krinner et al., 2006; Lambert et al., 2013). 
Clim. Past Discuss., https://doi.org/10.5194/cp-2017-102

Manuscript under review for journal Clim. Past

Discussion started: 21 August 2017

(c) Author(s) 2017. CC BY 4.0 License.

Climate

of the Past

Discussions

(c) (i)

\section{Data availability}

CISM2 diagnostic variables (mass-balance, ice thickness, surface topography, bedrock topography) at model year 5000 are archived in the USGS ScienceBase repository. The DOI of the dataset

5 is https://doi.org/10.5066/F7ZK5FK2. Additional time slices and variables are available upon request.

\section{Author contribution}

Jay Alder performed the ice sheet modeling and analysis. Steve Hostetler helped guide the experimental design and interpret the results. Both authors co-wrote the paper.

\section{Competing interests}

The authors declare that they have no conflict of interest.

\section{Acknowledgements}

We thank William Lipscomb, Matthew Hoffman, Stephen Price and everyone at Los Alamos National Laboratory on the CISM team for helping us configure and run the ice sheet model. Lauren Gregoire provided the North American domain and configuration files. We acknowledge the modelling

15 centres that contributed LGM simulations to the PMIP3/CMIP5 archive. A special thanks to Maureen Walczak for helpful feedback on our paper. 
Clim. Past Discuss., https://doi.org/10.5194/cp-2017-102

Manuscript under review for journal Clim. Past

Discussion started: 21 August 2017

(c) Author(s) 2017. CC BY 4.0 License.

\section{References}

Abe-Ouchi, A., Saito, F., Kageyama, M., Braconnot, P., Harrison, S. P., Lambeck, K., Otto-Bliesner, B. L., Peltier, W. R., Tarasov, L.,

5 Peterschmitt, J. Y. and Takahashi, K.: Ice-sheet configuration in the CMIP5/PMIP3 Last Glacial Maximum experiments, Geosci. Model Dev., 8(11), 3621-3637, doi:10.5194/gmd-8-3621-2015, 2015.

Abe-Ouchi, A., Segawa, T. and Saito, F.: Climatic Conditions for modelling the Northern Hemisphere ice sheets throughout the ice age cycle, Clim Past, 3(3), 423-438, 2007.

Alder, J. R. and Hostetler, S. W.: Global climate simulations at 3000-year intervals for the last 21000 years with the GENMOM coupled atmosphere-ocean model, Clim Past, 11(3), 449-471, doi:10.5194/cp-11-449-2015, 2015.

Alder, J. R., Hostetler, S. W., Pollard, D. and Schmittner, A.: Evaluation of a present-day climate simulation with a new coupled atmosphere-ocean model GENMOM, Geosci. Model Dev., 4(1), 69-83, doi:10.5194/gmd-4-69-2011, 2011.

Argus, D. F., Peltier, W. R., Drummond, R. and Moore, A. W.: The Antarctica component of postglacial rebound model ICE-6G_C (VM5a) based on GPS positioning, exposure age dating of ice thicknesses, and relative sea level histories, Geophys. J. Int., 198(1), 537-

15 563, doi:10.1093/gji/ggu140, 2014.

Bao, Q., Lin, P., Zhou, T., Liu, Y., Yu, Y., Wu, G., He, B., He, J., Li, L., Li, J., Li, Y., Liu, H., Qiao, F., Song, Z., Bin Wang, Wang, J., Wang, P., Wang, X., Wang, Z., Wu, B., Wu, T., Xu, Y., Yu, H., Zhao, W., Zheng, W. and Zhou, L.: The Flexible Global OceanAtmosphere-Land system model, Spectral Version 2: FGOALS-s2, Adv. Atmos. Sci., 30(3), 561-576, doi:10.1007/s00376-012-2113-9, 2013.

20 Bao, Q., Wu, G., Liu, Y., Yang, J., Wang, Z. and Zhou, T.: An introduction to the coupled model FGOALS1.1-s and its performance in East Asia, Adv. Atmos. Sci., 27(5), 1131-1142, doi:10.1007/s00376-010-9177-1, 2010.

Bartlein, P. J., Harrison, S. P., Brewer, S., Connor, S., Davis, B. A. S., Gajewski, K., Guiot, J., Harrison-Prentice, T. I., Henderson, A., Peyron, O., Prentice, I. C., Scholze, M., Seppä, H., Shuman, B., Sugita, S., Thompson, R. S., Viau, A. E., Williams, J. and Wu, H.: Pollenbased continental climate reconstructions at 6 and 21 ka: a global synthesis, Clim Dynam, 37(3-4), 775-802, doi:10.1007/s00382-010-

25 0904-1, 2011.

Bauer, E. and Ganopolski, A.: Sensitivity simulations with direct shortwave radiative forcing by aeolian dust during glacial cycles, Clim Past, 2014.

Braconnot, P., Harrison, S. P., Kageyama, M., Bartlein, P. J., Masson-Delmotte, V., Abe-Ouchi, A., Otto-Bliesner, B. L. and Zhao, Y.: Evaluation of climate models using palaeoclimatic data, Nat Geosci, 2(6), 417-424, doi:10.1038/nclimate1456, 2012.

30 Braconnot, P., Otto-Bliesner, B. L., Harrison, S., Joussaume, S., Peterschmitt, J. Y., Abe-Ouchi, A., Crucifix, M., Driesschaert, E., Fichefet, T., Hewitt, C. D., Kageyama, M., Kitoh, A., Laîné, A., Loutre, M. F., Marti, O., Merkel, U., Ramstein, G., Valdes, P., Weber, S. L., Yu, Y. and Zhao, Y.: Results of PMIP2 coupled simulations of the Mid-Holocene and Last Glacial Maximum - Part 1: experiments and large-scale features, 3(2), 261-277, 2007.

Charbit, S., Ritz, C., Philippon, G., Peyaud, V. and Kageyama, M.: Numerical reconstructions of the Northern Hemisphere ice sheets 35 through the last glacial-interglacial cycle, Clim Past, 3(1), 15-37, 2007. 
Clim. Past Discuss., https://doi.org/10.5194/cp-2017-102

Manuscript under review for journal Clim. Past

Discussion started: 21 August 2017

(c) Author(s) 2017. CC BY 4.0 License.

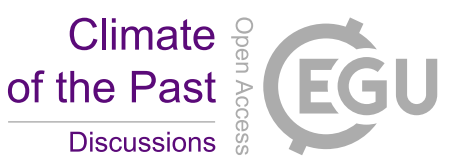

Clark, P. U., Dyke, A. S., Shakun, J. D., Carlson, A. E., Clark, J., Wohlfarth, B., Mitrovica, J. X., Hostetler, S. W. and McCabe, A. M.:

The Last Glacial Maximum, Science, 325(5941), 710-714, doi:10.1126/science.1172873, 2009.

COHMAP Members: Climatic Changes of the Last 18,000 Years - Observations and Model Simulations, Science, 241(4869), 1043-1052, 1988.

5 Dufresne, J. L., Foujols, M. A., Denvil, S., Caubel, A., Marti, O., Aumont, O., Balkanski, Y., Bekki, S., Bellenger, H., Benshila, R., Bony, S., Bopp, L., Braconnot, P., Brockmann, P., Cadule, P., Cheruy, F., Codron, F., Cozic, A., Cugnet, D., de Noblet, N., Duvel, J. P., Ethé, C., Fairhead, L., Fichefet, T., Flavoni, S., Friedlingstein, P., Grandpeix, J. Y., Guez, L., Guilyardi, E., Hauglustaine, D., Hourdin, F., Idelkadi, A., Ghattas, J., Joussaume, S., Kageyama, M., Krinner, G., Labetoulle, S., Lahellec, A., Lefebvre, M. P., Lefevre, F., Levy, C., Li, Z. X., Lloyd, J., Lott, F., Madec, G., Mancip, M., Marchand, M., Masson, S., Meurdesoif, Y., Mignot, J., Musat, I., Parouty, S., Polcher, J., Rio,

10 C., Schulz, M., Swingedouw, D., Szopa, S., Talandier, C., Terray, P., Viovy, N. and Vuichard, N.: Climate change projections using the IPSL-CM5 Earth System Model: from CMIP3 to CMIP5, Clim Dynam, 40(9-10), 2123-2165, doi:10.1007/s00382-012-1636-1, 2013.

Dyke, A. S.: An outline of North American deglaciation with emphasis on central and northern Canada, in Quaternary Glaciations-Extent and Chronology - Part II: North America, vol. 2, pp. 373-424, Elsevier. 2004.

Dyke, A. S. and Prest, V. K.: Late Wisconsinan and Holocene History of the Laurentide Ice Sheet, Geogr. Phys. Quatern., 41(2), 237-263, doi:10.7202/032681ar, 1987.

Ehlers, J.: Quaternary Glaciations - Extent and Chronology, 1st ed., edited by J. Ehlers, P. L. Gibbard, and P. D. Hughes, Elsevier, Amsterdam. 2011.

Flato, G. M., Marotzke, J., Abiodun, M., Braconnot, P., Chou, S. C., Collins, W., Cox, P., Driouech, F., Emori, S., Eyring, V., Forest, C. E., Gleckler, P., Guilyardi, E., Jakob, C., Kattsov, V., Reason, C. and Rummukainen, M.: Evaluation of Climate Models, in Climate

20 Change 2013 - The Physical Science Basis, edited by T. F. Stocker, D. Qin, G.-K. Plattner, M. Tignor, S. K. Allen, J. Boschung, A. Nauels, Y. Xia, V. Bex, and P. M. Midgley, pp. 1-126, Cambridge University Press, Cambridge, United Kingdom and New York, NY, USA. 2013.

Gent, P. R., Danabasoglu, G., Donner, L. J., Holland, M. M., Hunke, E. C., Jayne, S. R., Lawrence, D. M., Neale, R. B., Rasch, P. J., Vertenstein, M., Worley, P. H., Yang, Z.-L. and Zhang, M.: The Community Climate System Model Version 4, J Climate, 24(19), 49734991, doi:10.1175/2011JCLI4083.1, 2011.

Gregoire, L. J., Payne, A. J. and Valdes, P. J.: Deglacial rapid sea level rises caused by ice-sheet saddle collapses, Nature, 487(7406), 219222, doi:10.1038/nature11257, 2012.

Gregoire, L. J., Valdes, P. J. and Payne, A. J.: The relative contribution of orbital forcing and greenhouse gases to the North American deglaciation, Geophys. Res. Lett., 42(22), 9970-9979, doi:10.1002/2015GL066005, 2015.

30 Hargreaves, J. C., Annan, J. D., Ohgaito, R., Paul, A. and Abe-Ouchi, A.: Skill and reliability of climate model ensembles at the Last Glacial Maximum and mid-Holocene, Clim Past, 9(2), 811-823, doi:10.5194/cp-9-811-2013, 2013.

Harrison, S. P., Bartlein, P. J. and Prentice, I. C.: What have we learnt from palaeoclimate simulations?, edited by J. A. Holmes, P. A. Barker, and M. J. Leng, J. Quaternary Sci., 31(4), 363-385, doi:10.1002/jqs.2842, 2016.

Harrison, S. P., Bartlein, P. J., Brewer, S., Prentice, I. C., Boyd, M., Hessler, I., Holmgren, K., Izumi, K. and Willis, K.: Climate model benchmarking with glacial and mid-Holocene climates, Clim Dynam, 43(3-4), 671-688, doi:10.1007/s00382-013-1922-6, 2014.

Harrison, S. P., Bartlein, P. J., Izumi, K., Li, G., Annan, J., Hargreaves, J., Braconnot, P. and Kageyama, M.: Evaluation of CMIP5 palaeosimulations to improve climate projections, Nat Geosci, 5(8), 735-743, doi:10.1038/nclimate2649, 2015.

hebeler, F., Purves, R. S. and Jamieson, S. S. R.: The impact of parametric uncertainty and topographic error in ice-sheet modelling, Journal of Glaciology, 54(188), 899-919, doi:10.3189/002214308787779852, 2008. 
Clim. Past Discuss., https://doi.org/10.5194/cp-2017-102

Manuscript under review for journal Clim. Past

Discussion started: 21 August 2017

(c) Author(s) 2017. CC BY 4.0 License.

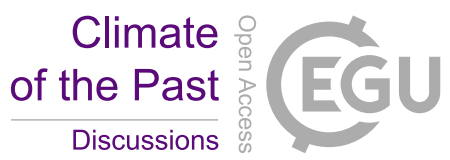

(c) (i)

Joussaume, S., Taylor, K. E., Braconnot, P., mitchell, J., Kutzbach, J. E., Harrison, S. P., Prentice, I. C., Broccoli, A. J., Abe-Ouchi, A., Bartlein, P. J., Bonfils, C., Dong, B., Guiot, J., Herterich, K., Hewitt, C. D., Jolly, D., Kim, J. W., Kislov, A., Kitoh, A., Loutre, M. F., Masson, V., McAvaney, B., McFarlane, N., de Noblet, N., Peltier, W. R., Peterschmitt, J. Y., Pollard, D., Rind, D., Royer, J. F., Schlesinger, M. E., Syktus, J., Thompson, S. L., Valdes, P., Vettoretti, G., Webb, R. S. and Wyputta, U.: Monsoon changes for 6000 years 5 ago: Results of 18 simulations from the Paleoclimate Modeling Intercomparison Project (PMIP), Geophys. Res. Lett., 26(7), 859-862, 1999.

Krinner, G., Boucher, O. and Balkanski, Y.: Ice-free glacial northern Asia due to dust deposition on snow, Clim Dynam, 27(6), 613-625, doi:10.1007/s00382-006-0159-z, 2006.

Lambert, F., Kug, J.-S., Park, R. J., Mahowald, N., Winckler, G., Abe-Ouchi, A., O 'ishi, R., Takemura, T. and Lee, J.-H.
mineral-dust aerosols in polar temperature amplification, Nat Geosci, 3(5), 487-491, doi:10.1038/nclimate1785, 2013.

Licciardi, J. M., Clark, P. U., Jenson, J. W. and Macayeal, D. R.: Deglaciation of a soft-bedded Laurentide Ice Sheet, Quaternary Sci Rev, 17(4-5), 427-448, doi:10.1016/S0277-3791(97)00044-9, 1998.

Lipscomb, W. H., Fyke, J. G., Vizcaino, M., Sacks, W. J., Wolfe, J., Vertenstein, M., Craig, A., Kluzek, E. and Lawrence, D. M.: Implementation and Initial Evaluation of the Glimmer Community Ice Sheet Model in the Community Earth System Model, J Climate,

26(19), 7352-7371, doi:10.1175/JCLI-D-12-00557.1, 2013.

Lunt, D. J., Foster, G. L., Haywood, A. M. and Stone, E. J.: Late Pliocene Greenland glaciation controlled by a decline in atmospheric CO2 levels, Nature, 454(7208), 1102-1105, doi:10.1038/nature07223, 2008.

Marshall, S. J. and Clarke, G. K. C.: Modeling North American Freshwater Runoff through the Last Glacial Cycle, Quaternary Research, 52(3), 300-315, doi:10.1006/qres.1999.2079, 1999.

20 Marshall, S. J., James, T. S. and Clarke, G. K. C.: North American Ice Sheet reconstructions at the Last Glacial Maximum, Quaternary Sci Rev, 21(1-3), 175-192, doi:10.1016/S0277-3791(01)00089-0, 2002.

Otto-Bliesner, B. L., Brady, E. C., Clauzet, G., Tomas, R., Levis, S. and Kothavala, Z.: Last Glacial Maximum and Holocene climate in CCSM3, J Climate, 19(11), 2526-2544, doi:10.1175/Jcli3748.1, 2006.

Peltier, W. R.: Ice-Age Paleotopography, Science, 265(5169), 195-201, doi:10.1126/science.265.5169.195, 1994.

25 Peltier, W. R.: Global glacial isostasy and the surface of the ice-age earth: The ice-5G(VM2) model and grace, Annual Review of Earth and Planetary Sciences, 32(1), 111-149, doi:10.1146/annurev.earth.32.082503.144359, 2004.

Peltier, W. R., Argus, D. F. and Drummond, R.: Space geodesy constrains ice age terminal deglaciation: The global ICE-6G_C (VM5a) model, J. Geophys. Res. Solid Earth, 120(1), 450-487, doi:10.1002/2014JB011176, 2015.

Pinot, S., Ramstein, G., Harrison, S. P., Prentice, I. C., Guiot, J., Stute, M. and Joussaume, S.: Tropical paleoclimates at the Last Glacial

30 Maximum: comparison of Paleoclimate Modeling Intercomparison Project (PMIP) simulations and paleodata, Clim Dynam, 15(11), 857874, 1999.

Pollard, D.: Comparisons of ice-sheet surface mass budgets from Paleoclimate Modeling Intercomparison Project (PMIP) simulations, Global Planet Change, 24(2), 79-106, doi:10.1016/S0921-8181(99)00071-5, 2000.

Price, S., Lipscomb, W. H., Hoffman, M., Hagdorn, M., Payne, T., hebeler, F. and kennedy, J. H.: Community Ice Sheet Model (CISM) 35 v2.0.5 Documentation, Los Alamos, NM. [online] Available from: http://oceans11.lanl.gov/cism/data/cism_documentation_v2.0.pdf, 2015.

Reeh, N.: Parameterization of melt rate and surface temperature on the Greenland ice sheet, Polarforschung, 59(3), 113-128, 1991. 
Clim. Past Discuss., https://doi.org/10.5194/cp-2017-102

Manuscript under review for journal Clim. Past

Discussion started: 21 August 2017

(c) Author(s) 2017. CC BY 4.0 License.

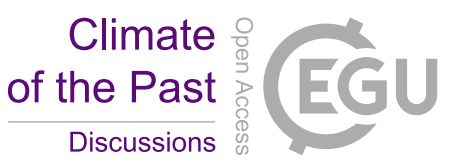

(c) $\underset{\mathrm{Br}}{\mathrm{B}}$

Rutt, I. C., Hagdorn, M., Hulton, N. R. J. and Payne, A. J.: The Glimmer community ice sheet model, J. Geophys. Res., 114(F2), doi:10.1029/2008JF001015, 2009.

Schmidt, G. A., Ruedy, R., Hansen, J. E., Aleinov, I., Bell, N., Bauer, M., Bauer, S., Cairns, B., Canuto, V., Cheng, Y., Del Genio, A., Faluvegi, G., Friend, A. D., Hall, T. M., Hu, Y., Kelley, M., Kiang, N. Y., Koch, D., Lacis, A. A., Lerner, J., Lo, K. K., Miller, R. L.,

5 Nazarenko, L., Oinas, V., Perlwitz, J., Rind, D., Romanou, A., Russell, G. L., Sato, M., Stone, P. H., Sun, S., Tausnev, N., Thresher, D., Yao, M.-S., Ruedy, R., Hansen, J. E., Aleinov, I., Bell, N., Bauer, M., Bauer, S., Cairns, B., Canuto, V., Cheng, Y., Del Genio, A., Faluvegi, G., Friend, A. D., Hall, T. M., Hu, Y., Kelley, M., Kiang, N. Y., Koch, D., Lacis, A. A., Lerner, J., Lo, K. K., Miller, R. L., Nazarenko, L., Oinas, V., Perlwitz, J., Perlwitz, J., Rind, D., Romanou, A., Russell, G. L., Sato, M., Shindell, D. T., Stone, P. H., Sun, S., Tausnev, N., Thresher, D. and Yao, M.-S.: Present-Day Atmospheric Simulations Using GISS ModelE: Comparison to In Situ, Satellite,

10 and Reanalysis Data, http://dx.doi.org/10.1175/JCLI3612.1, 19(2), 153-192, doi:10.1175/JCLI3612.1, 2006.

Schmittner, A., Silva, T. A. M., Fraedrich, K., Kirk, E. and Lunkeit, F.: Effects of Mountains and Ice Sheets on Global Ocean Circulation, J Climate, 24(11), 2814-2829, doi:10.1175/2010jcli3982.1, 2011.

Stone, E. J., Lunt, D. J., Rutt, I. C. and Hanna, E.: Investigating the sensitivity of numerical model simulations of the modern state of the Greenland ice-sheet and its future response to climate change, The Cryosphere, 4(3), 397-417, doi:10.5194/tc-4-397-2010, 2010.

15 Ullman, D. J., Carlson, A. E., Anslow, F. S., LeGrande, A. N. and Licciardi, J. M.: Laurentide ice-sheet instability during the last deglaciation, Nature Geosci, 8(7), 534-537, doi:10.1038/ngeo2463, 2015.

Ullman, D. J., LeGrande, A. N., Carlson, A. E., Anslow, F. S. and Licciardi, J. M.: Assessing the impact of Laurentide Ice Sheet topography on glacial climate, Clim Past, 10(2), 487-507, doi:10.5194/cp-10-487-2014, 2014.

Voldoire, A., Sanchez-Gomez, E., Salas y Melia, D., Decharme, B., Cassou, C., Senesi, S., Valcke, S., Beau, I., Alias, A., Chevallier, M., 20 Deque, M., Deshayes, J., Douville, H., Fernandez, E., Madec, G., Maisonnave, E., Moine, M.-P., Planton, S., Saint-Martin, D., Szopa, S., Tyteca, S., Alkama, R., Belamari, S., Braun, A., Coquart, L. and Chauvin, F.: The CNRM-CM5.1 global climate model: description and basic evaluation, Clim Dynam, 40(9-10), 2091-2121, doi:10.1007/s00382-011-1259-y, 2013.

Watanabe, S., Hajima, T., Sudo, K., Nagashima, T., Takemura, T., Okajima, H., Nozawa, T., Kawase, H., Abe, M., Yokohata, T., Ise, T., Sato, H., Kato, E., Takata, K., Emori, S. and Kawamiya, M.: MIROC-ESM 2010: model description and basic results of CMIP5-20c3m experiments, Geosci. Model Dev., 4(4), 845-872, doi:10.5194/gmd-4-845-2011, 2011.

Yukimoto, S., Adachi, Y., Hosaka, M., Sakami, T., Yoshimura, H., Hirabara, M., Tanaka, T. Y., Shindo, E., Tsujino, H., Deushi, M., MIZUTA, R., Yabu, S., Obata, A., Nakano, H., KOSHIRO, T., Ose, T. and Kitoh, A.: A New Global Climate Model of the Meteorological Research Institute: MRI-CGCM3 --Model Description and Basic Performance, JMSJ, 90A(0), 23-64, doi:10.2151/jmsj.2012-A02, 2012.

Yukimoto, S., Yoshimura, H., Hosaka, M., Sakami, T., Tsujino, H., Hirabara, M., Tanaka, T. Y., Deushi, M., Obata, A., Nakano, H.,

30 Adachi, Y., Shindo, E., Yabu, S., Ose, T. and Kitoh, A.: Meteorological Research Institute-Earth System 820 Model v1 (MRI-ESM1) Model Description, Meteorological Research Institute. 2011.

Zweck, C. and Huybrechts, P.: Modeling of the northern hemisphere ice sheets during the last glacial cycle and glaciological sensitivity, J.-Geophys.-Res., 110(D7), doi:10.1029/2004JD005489, 2005. 
Clim. Past Discuss., https://doi.org/10.5194/cp-2017-102

Manuscript under review for journal Clim. Past

Discussion started: 21 August 2017

(c) Author(s) 2017. CC BY 4.0 License.

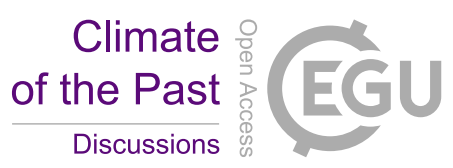

Table 1 CISM2 parameters used in experiments

\begin{tabular}{|l|l|l|}
\hline Parameter & Values & Units \\
\hline PDD factor of snow & $3,4,5$ & $\mathrm{~mm} \mathrm{~d}^{-1}{ }^{\circ} \mathrm{C}^{-1}$ \\
\hline PDD factor of ice & $8,12,16,20$ & $\mathrm{~mm} \mathrm{~d}^{-1}{ }^{\circ} \mathrm{C}^{-1}$ \\
\hline Refrozen meltwater & 60 & $\%$ \\
\hline Lapse & 5 & ${ }^{\circ} \mathrm{C} \mathrm{km}^{-1}$ \\
\hline Flow factor & 5 & - \\
\hline Basal sliding parameter on sediment & 10 & $\mathrm{~mm} \mathrm{yr}^{-1} \mathrm{~Pa}^{-1}$ \\
\hline Basal sliding parameter on bare rock & 0.5 & $\mathrm{~mm} \mathrm{yr}^{-1} \mathrm{~Pa}^{-1}$ \\
\hline Mantle relaxation time & 1000 & $\mathrm{yr}$ \\
\hline Marine limit & -400 & $\mathrm{~m}$ \\
\hline
\end{tabular}


Clim. Past Discuss., https://doi.org/10.5194/cp-2017-102

Climate

Manuscript under review for journal Clim. Past

Discussion started: 21 August 2017

(c) Author(s) 2017. CC BY 4.0 License.

Table 2 PMIP3 LGM models (info from IPCC AR5 Table 9.A.1). *The GENMOM simulation was not submitted to PMIP3.

\begin{tabular}{|c|c|c|c|c|c|}
\hline Model Name & Institution & Reference & Atmospheric resolution & $\begin{array}{l}\text { Ice sheet } \\
\text { configuration }\end{array}$ & rip \\
\hline CCSM4 & $\begin{array}{l}\text { National Centre for } \\
\text { Atmospheric } \\
\text { Research }\end{array}$ & (Gent et al., 2011) & $\begin{array}{l}0.9^{\circ} \times 1.25^{\circ} \\
{[288 \times 192]}\end{array}$ & $\begin{array}{l}\text { CMIP5/PMIP3 } \\
\text { blended }\end{array}$ & r1ilp1 \\
\hline CNRM-CM5 & $\begin{array}{l}\text { Centre National de } \\
\text { Recherches } \\
\text { Meteorologiques } \\
\text { and Centre } \\
\text { Europeen de } \\
\text { Recherche et } \\
\text { Formation } \\
\text { Avancees en Calcul } \\
\text { Scientifique. }\end{array}$ & (Voldoire et al., 2013) & $\begin{array}{l}\text { TL127 } \\
{[256 \times 128]}\end{array}$ & $\begin{array}{l}\text { CMIP5/PMIP3 } \\
\text { blended }\end{array}$ & r1ilp1 \\
\hline FGOALS-g2 & $\begin{array}{l}\text { LASG (Institute of } \\
\text { Atmospheric } \\
\text { Physics)- } \\
\text { CESS(Tsinghua } \\
\text { University) } \\
\end{array}$ & (Bao et al., 2013; 2010) & $\begin{array}{l}\mathrm{R} 42 \\
2.81^{\circ} \times 1.66^{\circ} \\
{[128 \times 60]}\end{array}$ & $\begin{array}{l}\text { CMIP5/PMIP3 } \\
\text { blended }\end{array}$ & r1i1p1 \\
\hline GENMOM $^{*}$ & $\begin{array}{l}\text { U.S. Geological } \\
\text { Survey / Oregon } \\
\text { State University }\end{array}$ & $\begin{array}{l}\text { (Alder and Hostetler, } \\
\text { 2015; Alder et al., } \\
\text { 2011) }\end{array}$ & $\begin{array}{l}\mathrm{T} 31 \\
3.75^{\circ} \times 3.75^{\circ} \\
{[96 \times 48]}\end{array}$ & $\begin{array}{l}\text { ICE-4G + Licciardi } \\
\text { et al. (1998) } 1814 C \\
\text { ka vMx }\end{array}$ & \\
\hline GISS-E2-R & $\begin{array}{l}\text { NASA Goddard } \\
\text { Institute for Space } \\
\text { Studies USA }\end{array}$ & (Schmidt et al., 2006) & $\begin{array}{l}2^{\circ} \times 2.5^{\circ} \\
{[144 \times 90]}\end{array}$ & $\begin{array}{l}\text { ICE-5G + Licciardi } \\
\text { et al. (1998) } 1814 \mathrm{C} \\
\text { ka Mx }\end{array}$ & r1ilp151 \\
\hline $\begin{array}{l}\text { IPSL-CM5A- } \\
\text { LR }\end{array}$ & $\begin{array}{l}\text { Institut Pierre } \\
\text { Simon Laplace }\end{array}$ & (Dufresne et al., 2013) & $\begin{array}{l}\text { LMDZ96 } \\
1.9^{\circ} \times 3.75^{\circ} \\
{[96 \times 96]}\end{array}$ & $\begin{array}{l}\text { CMIP5/PMIP3 } \\
\text { blended }\end{array}$ & r1i1p1 \\
\hline MIROC-ESM & $\begin{array}{l}\text { University of } \\
\text { Tokyo, National } \\
\text { Institute for } \\
\text { Environmental } \\
\text { Studies, and Japan } \\
\text { Agency for Marine- } \\
\text { Earth Science and } \\
\text { Technology }\end{array}$ & (Watanabe et al., 2011) & $\begin{array}{l}\text { T42 } \\
2.8125 \times 2.8125^{\circ} \\
{[128 \times 64]}\end{array}$ & $\begin{array}{l}\text { CMIP5/PMIP3 } \\
\text { blended }\end{array}$ & r1ilp1 \\
\hline MPI-ESM-P & $\begin{array}{l}\text { Max Planck } \\
\text { Institute for } \\
\text { Meteorology }\end{array}$ & & $\begin{array}{l}\text { T63 } \\
1.8^{\circ} \\
{[192 \times 96]}\end{array}$ & $\begin{array}{l}\text { CMIP5/PMIP3 } \\
\text { blended }\end{array}$ & r1ilp1 \\
\hline MRI-CGCM3 & $\begin{array}{l}\text { Meteorological } \\
\text { Research Institute }\end{array}$ & $\begin{array}{l}\text { (Yukimoto et al., 2012; } \\
\text { 2011) }\end{array}$ & $\begin{array}{l}\text { TL159 } \\
{[320 \times 160]}\end{array}$ & $\begin{array}{l}\text { CMIP5/PMIP3 } \\
\text { blended }\end{array}$ & r1ilp1 \\
\hline
\end{tabular}


Clim. Past Discuss., https://doi.org/10.5194/cp-2017-102

Manuscript under review for journal Clim. Past

Discussion started: 21 August 2017

(c) Author(s) 2017. CC BY 4.0 License.

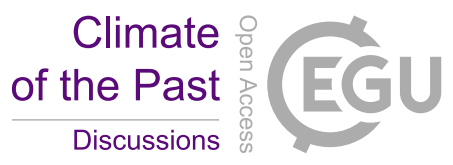

(c) $($ i)

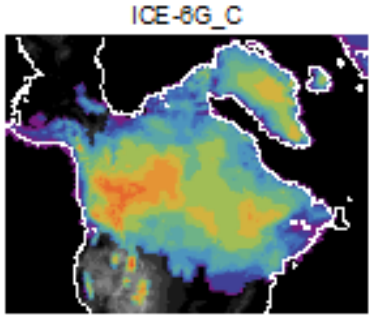

CMIP5/PMIP3
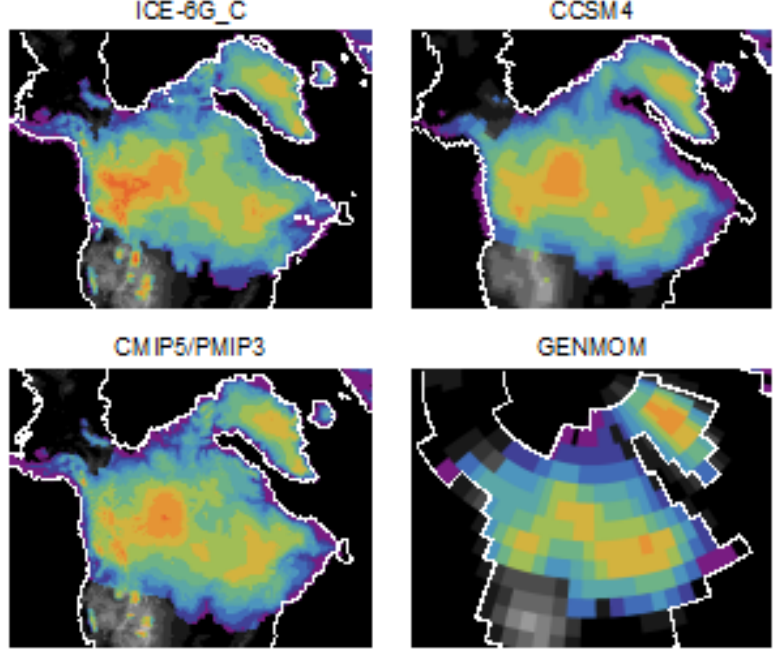

GENMOM

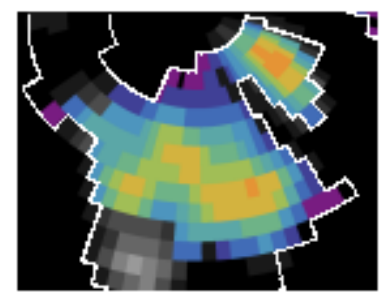

MIROC-ESM
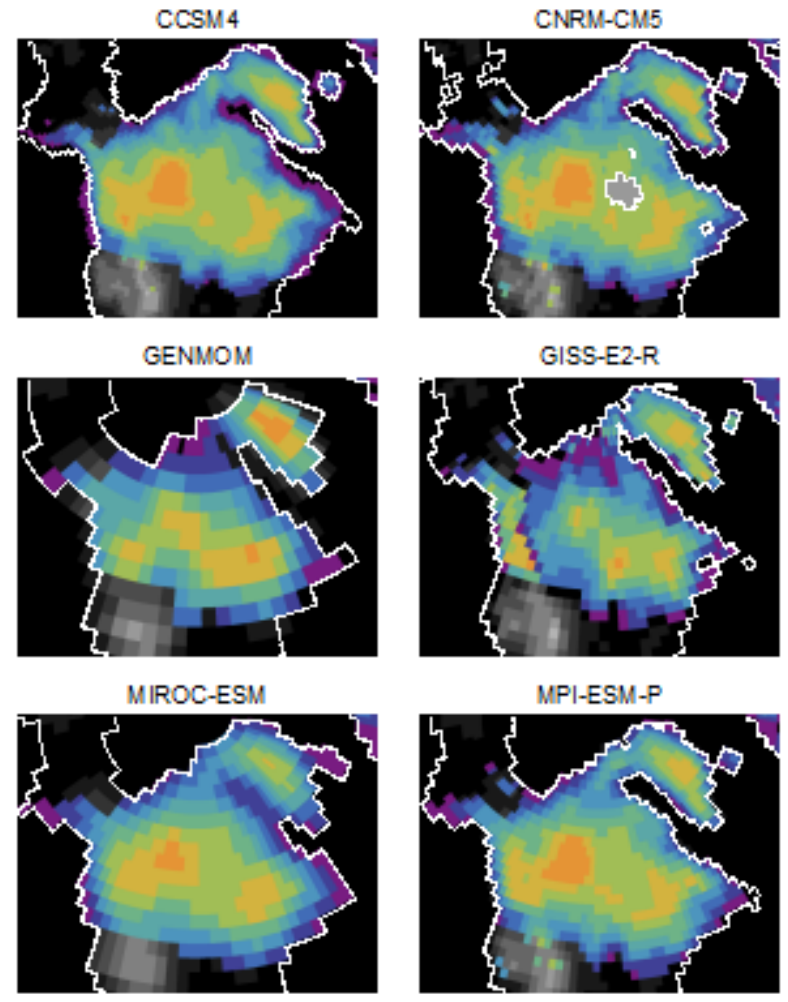

GISS-E2-R

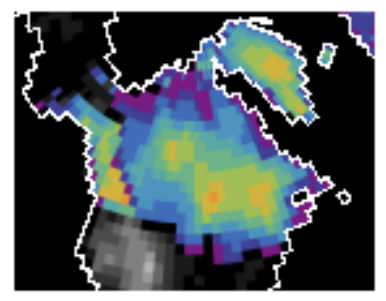

MPI-ESM-P
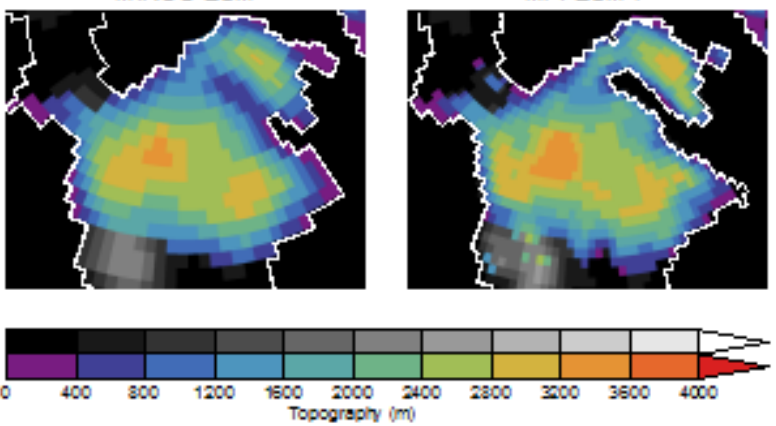

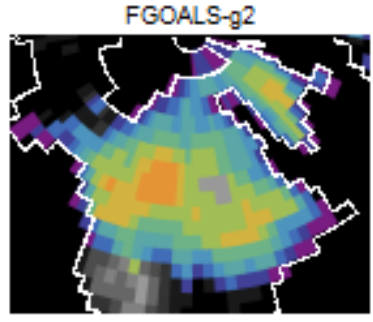

IP SL-CM5A-LR

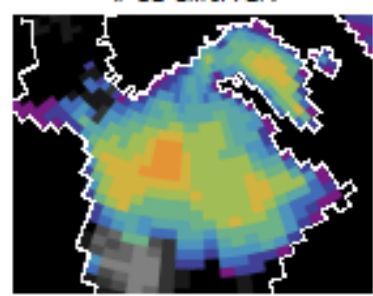

MRI-CGCM 3

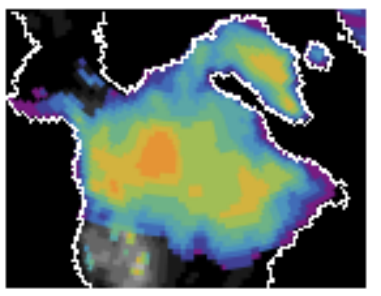

Figure 1: LGM North American ice sheet topography from ICE-6G_C (Argus et al., 2014; Peltier et al., 2015), the blended CMIP5/PMIP3 (Abe-Ouchi et al., 2015), and the GCM ice sheet configurations (see Table 2). The rainbow colour pallet corresponds

to grid cells that are $\geq \mathbf{5 0 \%}$ ice covered. 
Clim. Past Discuss., https://doi.org/10.5194/cp-2017-102

Manuscript under review for journal Clim. Past

Discussion started: 21 August 2017

(c) Author(s) 2017. CC BY 4.0 License.

Climate of the Past

(c) (i)

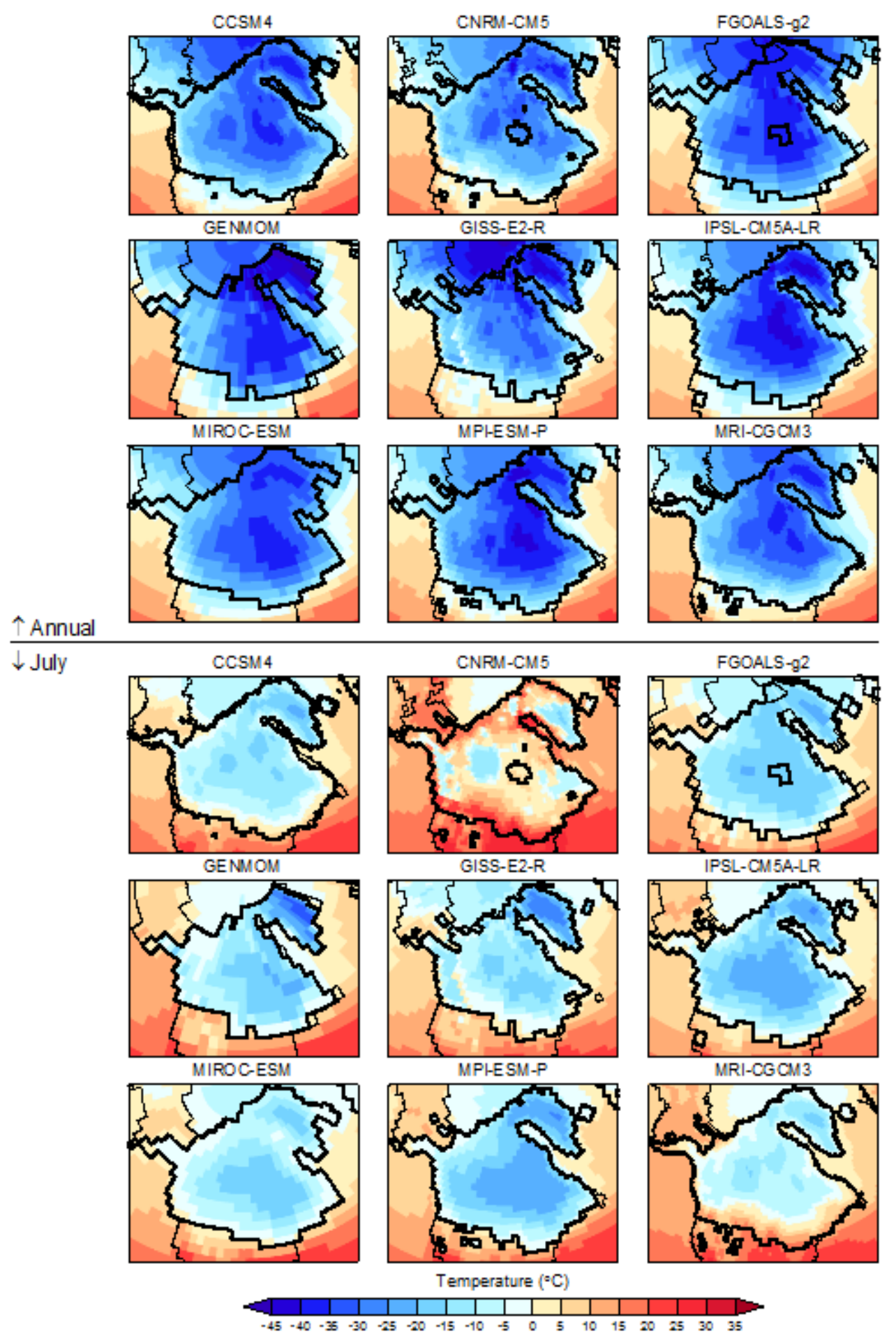

Figure 2: LGM mean annual and July near surface air temperature climatologies. The ice sheet outline for each GCM is indicated by the bold black line. 
Clim. Past Discuss., https://doi.org/10.5194/cp-2017-102

Manuscript under review for journal Clim. Past

Discussion started: 21 August 2017

(c) Author(s) 2017. CC BY 4.0 License.

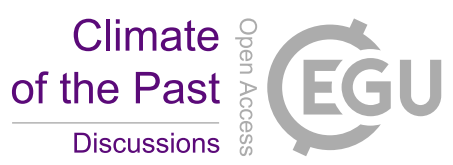

(c) $\underset{\mathrm{BY}}{\mathrm{B}}$
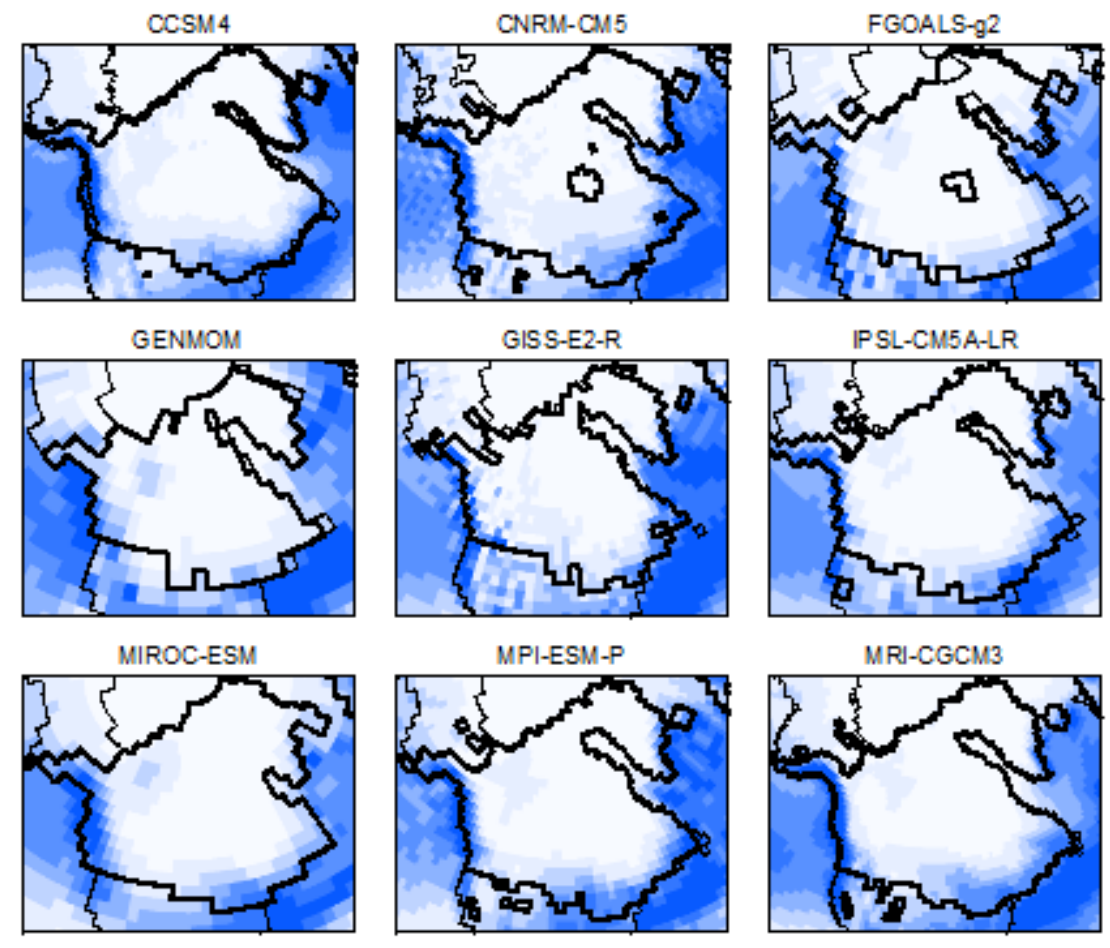

Precipitation (m)

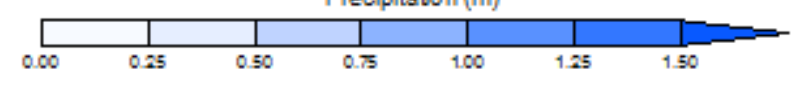

Figure 3: As in Fig. 2 for mean annual precipitation. 
Clim. Past Discuss., https://doi.org/10.5194/cp-2017-102

Manuscript under review for journal Clim. Past

Discussion started: 21 August 2017

(c) Author(s) 2017. CC BY 4.0 License.

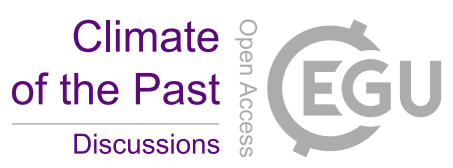

(c) (i)

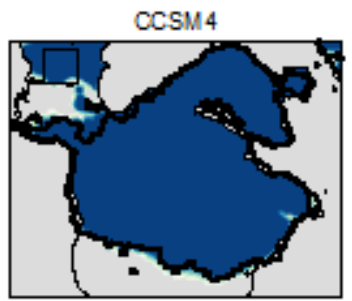

GENMOM

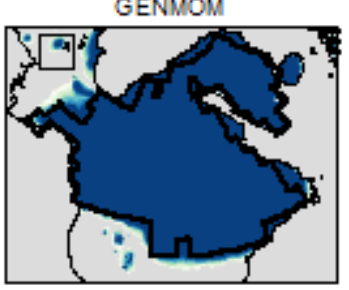

MIROC-ESM
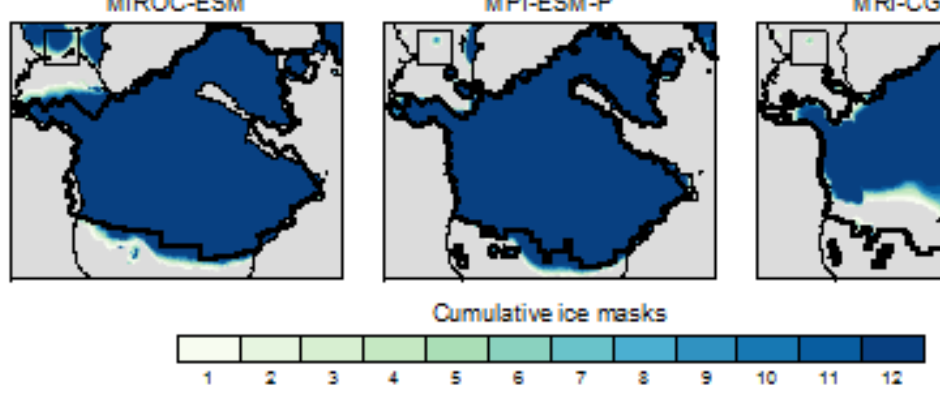
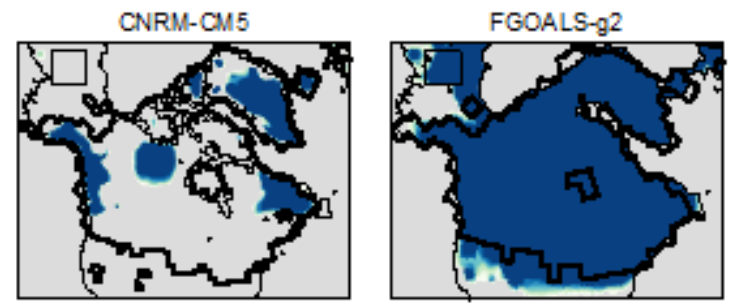

GISS-E2-R

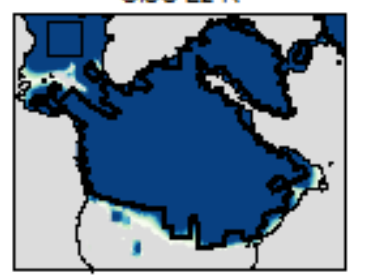

IPSL-CM5A-LR

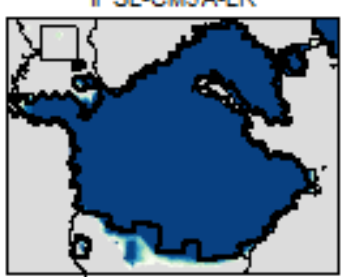

MPI-ESM-P
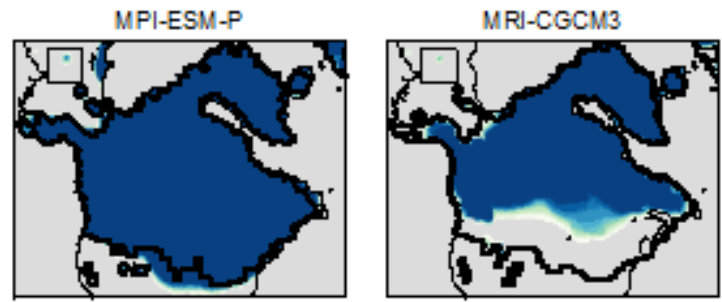

Figure 4: Cumulative ice presence masks for the twelve PDD realizations. The PDD factors were varied in twelve combinations of $[3,4,5] \mathrm{mm} \mathrm{d}^{\circ} \mathrm{C}^{-1}$ for snow and $[8,12,16,20] \mathrm{mm} \mathrm{d}^{-1}{ }^{\circ} \mathrm{C}^{-1}$ for ice. Colours indicates where CISM2 simulated ice presence. Ice is considered present if the thickness is $\geq 1 \mathrm{~m}$. The original GCM ice sheet outline is indicated by the bold black line. The black box in the northwest part of the domain indicates the location for the Beringia analysis (Section 4.2). 
Clim. Past Discuss., https://doi.org/10.5194/cp-2017-102

Manuscript under review for journal Clim. Past

Discussion started: 21 August 2017

(c) Author(s) 2017. CC BY 4.0 License.
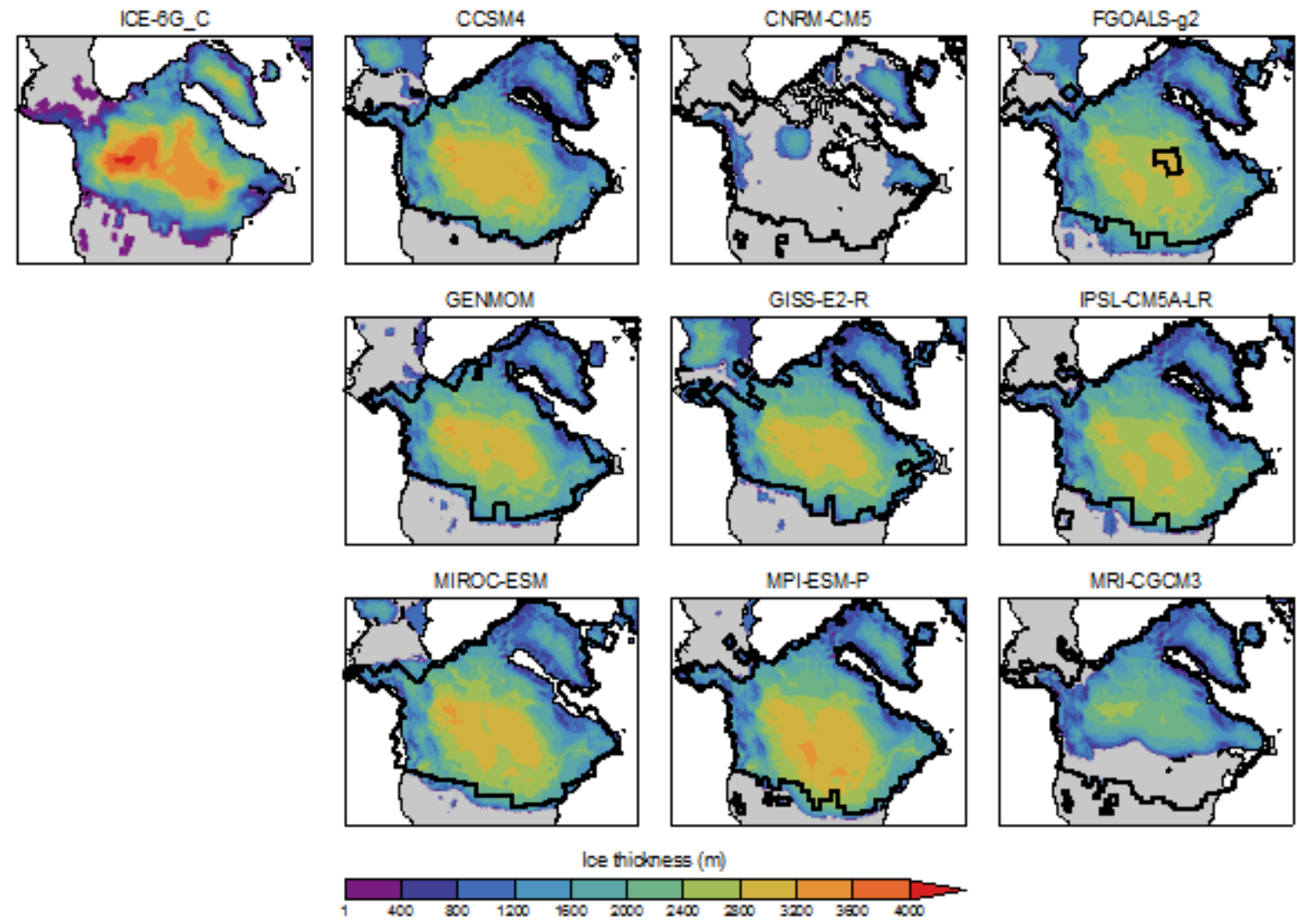

Climate of the Past

Discussions

(c) 
Clim. Past Discuss., https://doi.org/10.5194/cp-2017-102

Manuscript under review for journal Clim. Past

Discussion started: 21 August 2017

(c) Author(s) 2017. CC BY 4.0 License.
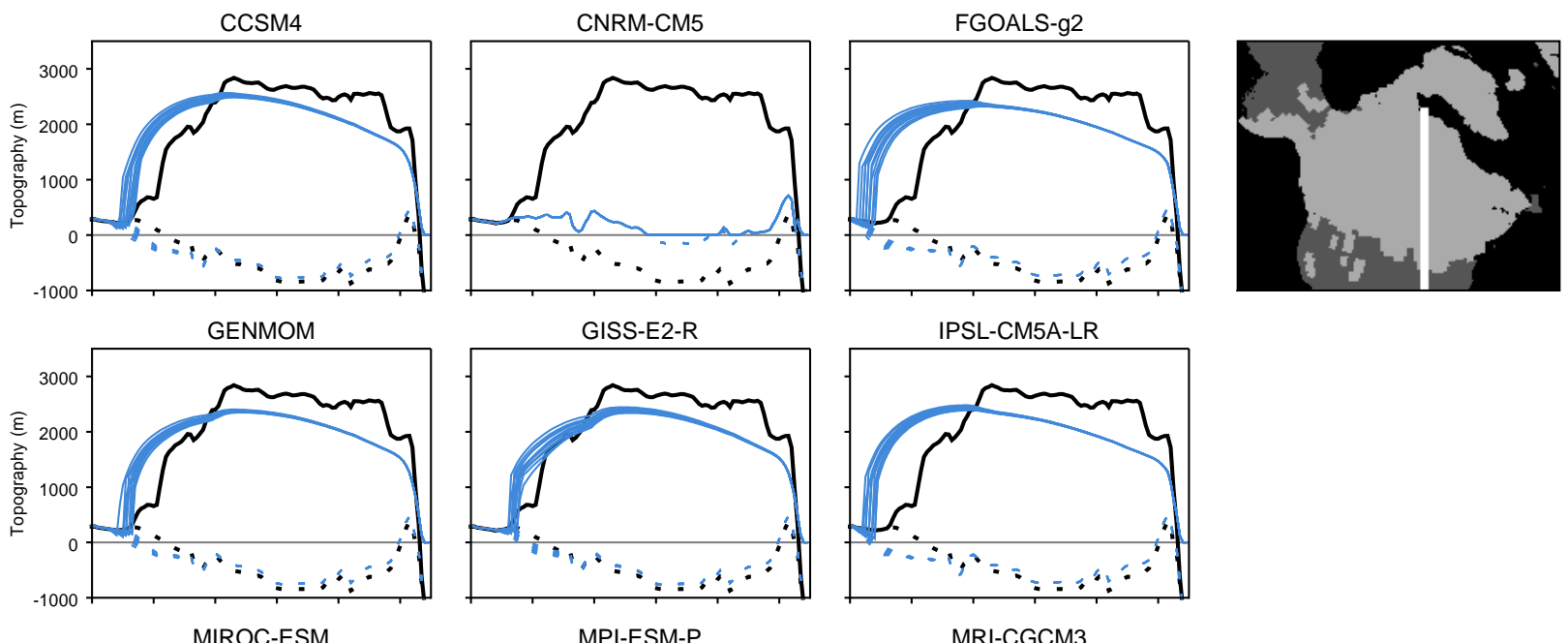

IPSL-CM5A-LR
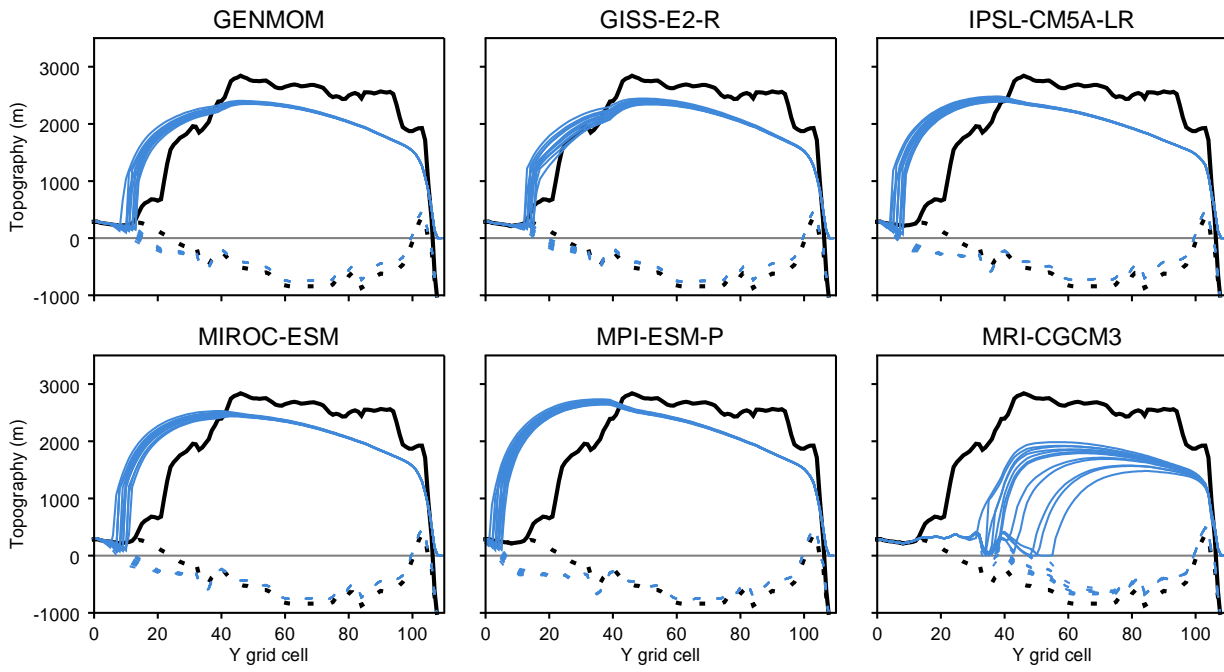

MRI-CGCM3

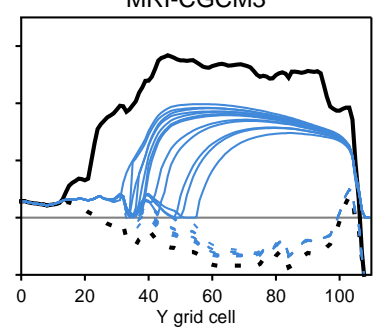
— ICE-6G_C surface
- - ICE-6G_C bedrock
- CISM2 surface

- - CISM2 bedrock

Figure 6: South to north cross sections of ice sheet topography and bedrock deformation in the ICE-6G_C reconstruction and as simulated with twelve PDD combinations for each GCM. The location of the cross section is indicated by the white line in the map on the upper right of the figure. The southern edge of the ice corresponds to zero on the $x$ axes. 
Clim. Past Discuss., https://doi.org/10.5194/cp-2017-102

Manuscript under review for journal Clim. Past

Discussion started: 21 August 2017

(c) Author(s) 2017. CC BY 4.0 License.

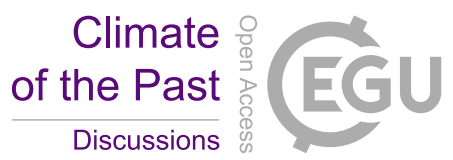

(c) $\underset{\mathrm{BY}}{\mathrm{Br}}$
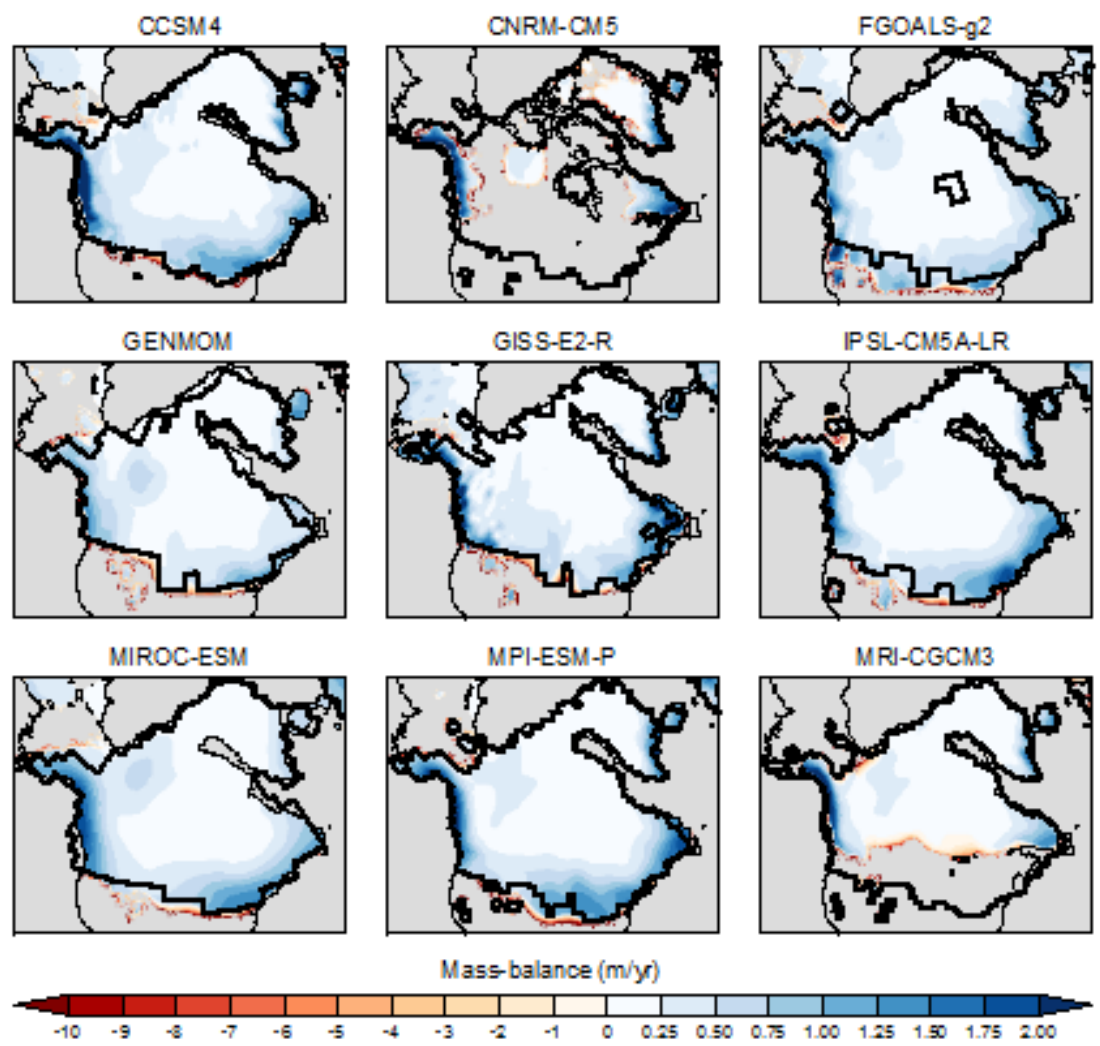

Figure 7: Surface mass balance after 5000 years of simulation using PDD factors of $4 \mathrm{~d}^{-1}{ }^{\circ} \mathrm{C}^{-1}$ for snow and $16 \mathrm{~mm} \mathrm{~d}^{-1}{ }^{\circ} \mathrm{C}^{-1}$ for ice in the CISM2. The original GCM ice sheet outline is indicated by the bold black line. 
Clim. Past Discuss., https://doi.org/10.5194/cp-2017-102

Manuscript under review for journal Clim. Past

Discussion started: 21 August 2017

(c) Author(s) 2017. CC BY 4.0 License.

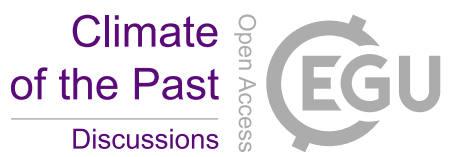

(c) (1)

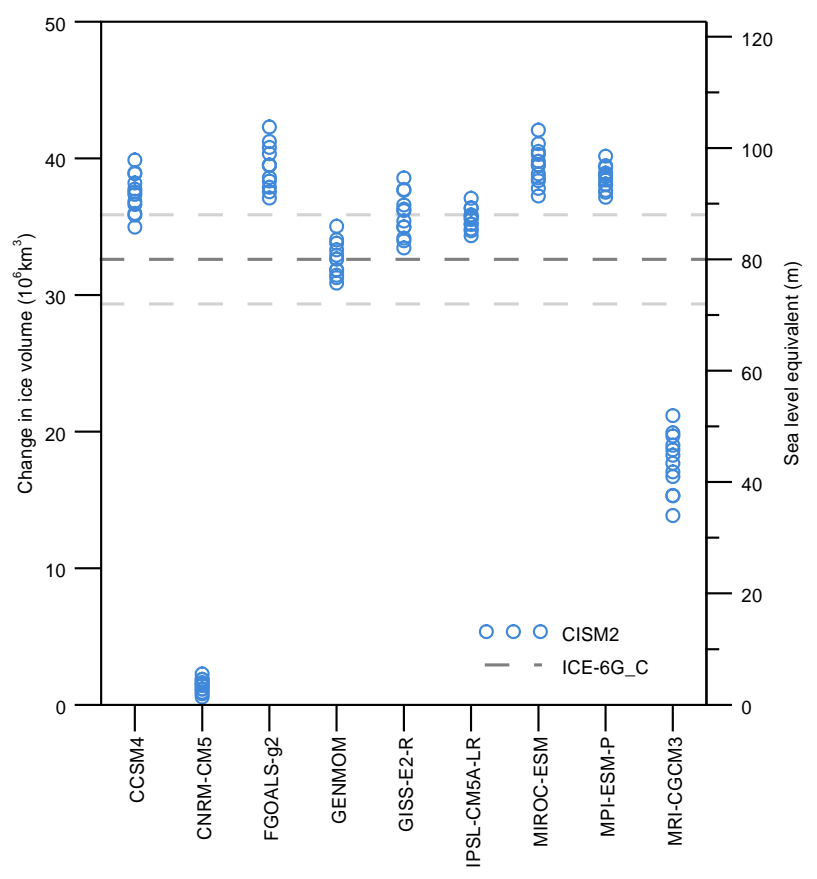

Figure 8: North American ice volume and sea level equivalent for the 12 PDD realizations. The circles for each GCM indicate the range of volume simulated by CISM2 for each PDD factor pairs. The light grey dashed lines represent $\pm 10 \%$ of the $32.6 \times 10^{6} \mathrm{~km}^{3}$ volume of ICE-6G_C indicated by the dark dashed line. Sea level equivalent is calculated as the eustatic change from converting land ice to water, using 910 and $1028 \mathrm{~kg} \mathrm{~m}^{-3}$ densities for ice and water respectively, assuming an ocean area of $360768576 \mathrm{~km}^{2}$. All models were initialized with the ICE-6G_C volume, thus the displayed values are GCM-forced deviations from ICE-6G_C after 5000 simulated years. 
Clim. Past Discuss., https://doi.org/10.5194/cp-2017-102

Manuscript under review for journal Clim. Past

Discussion started: 21 August 2017

(c) Author(s) 2017. CC BY 4.0 License.

\section{Climate of the Past \\ Discussions}

(c) (i)

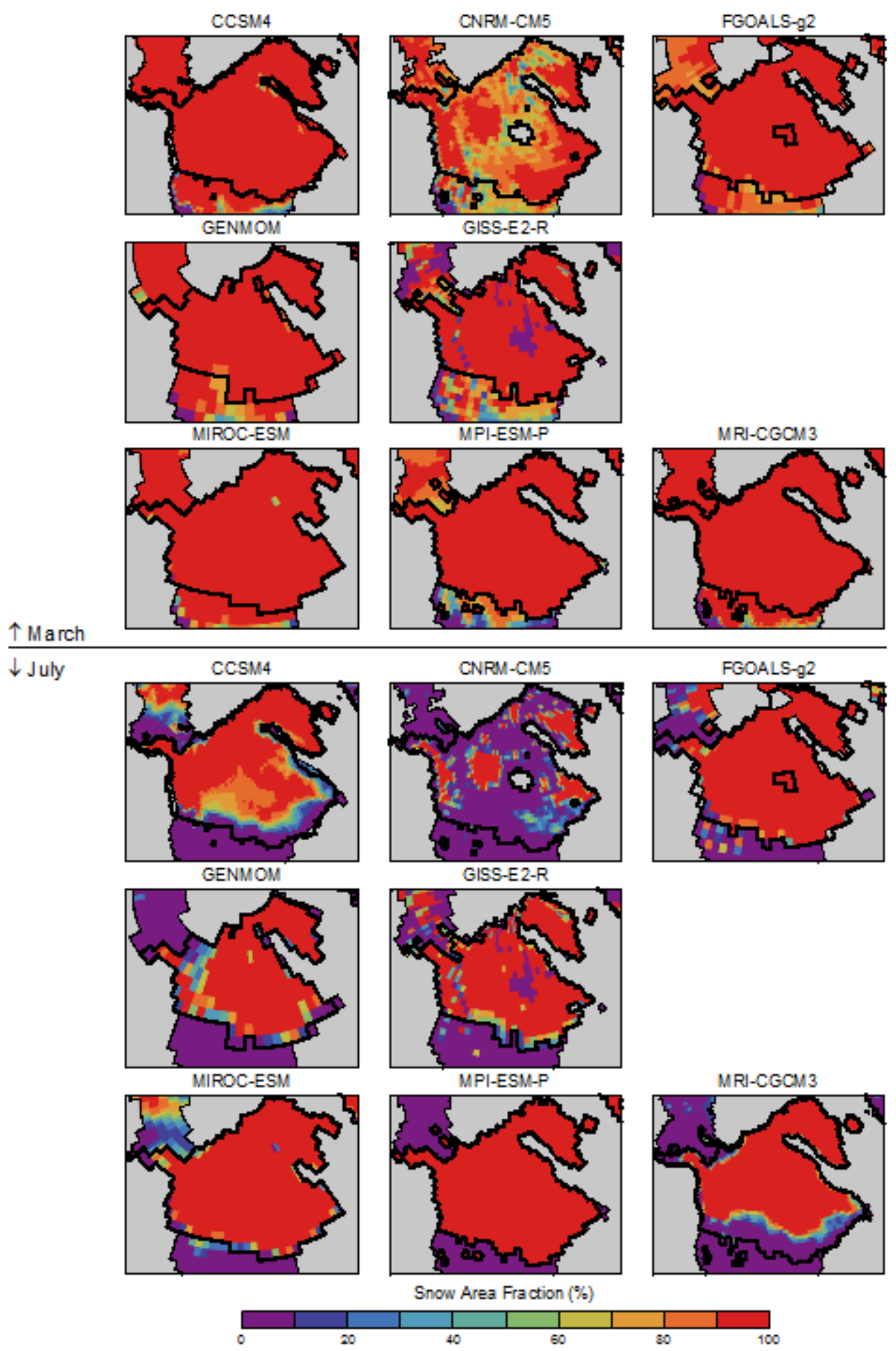

Figure 9: GCM March and July fractional snow coverage. Snow coverage for IPSL-CM5A-LR was not available from the CMIP5 archive at the time of writing. 
Clim. Past Discuss., https://doi.org/10.5194/cp-2017-102

Manuscript under review for journal Clim. Past

Discussion started: 21 August 2017

(c) Author(s) 2017. CC BY 4.0 License.

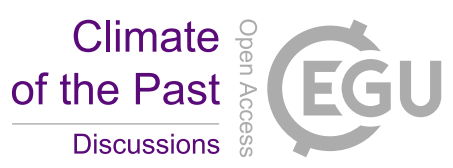

(c) (i)
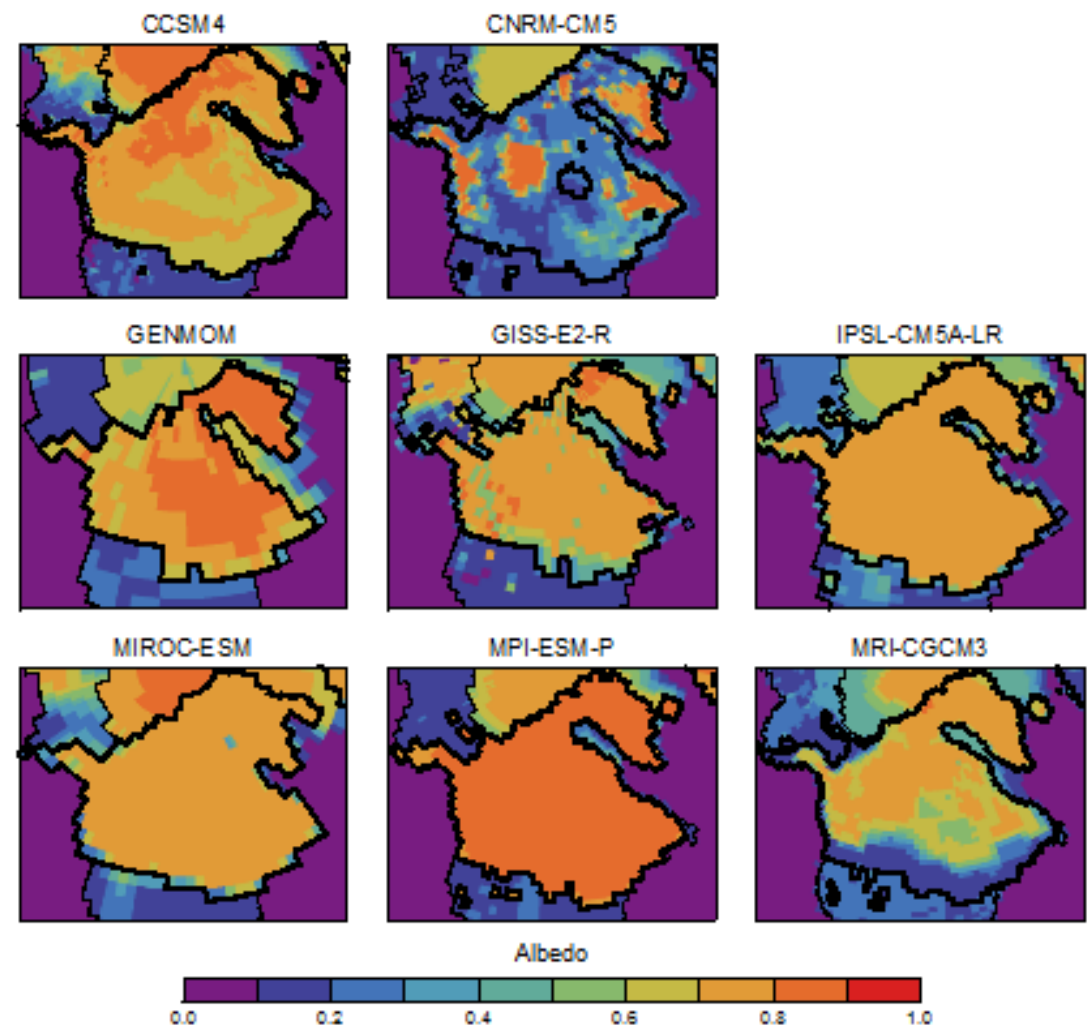

Figure 10: GCM July albedo. Visible band albedo is calculated as shortwave upward radiation divided by shortwave downward radiation (SW / SW $\downarrow$ ) at the surface. Shortwave upward radiation for FGOALS-g2 was not available from the CMIP5 archive at the time of writing. 
Clim. Past Discuss., https://doi.org/10.5194/cp-2017-102

Manuscript under review for journal Clim. Past

Discussion started: 21 August 2017

(c) Author(s) 2017. CC BY 4.0 License.

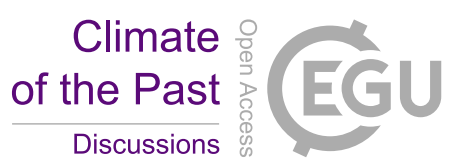

(c) (i)
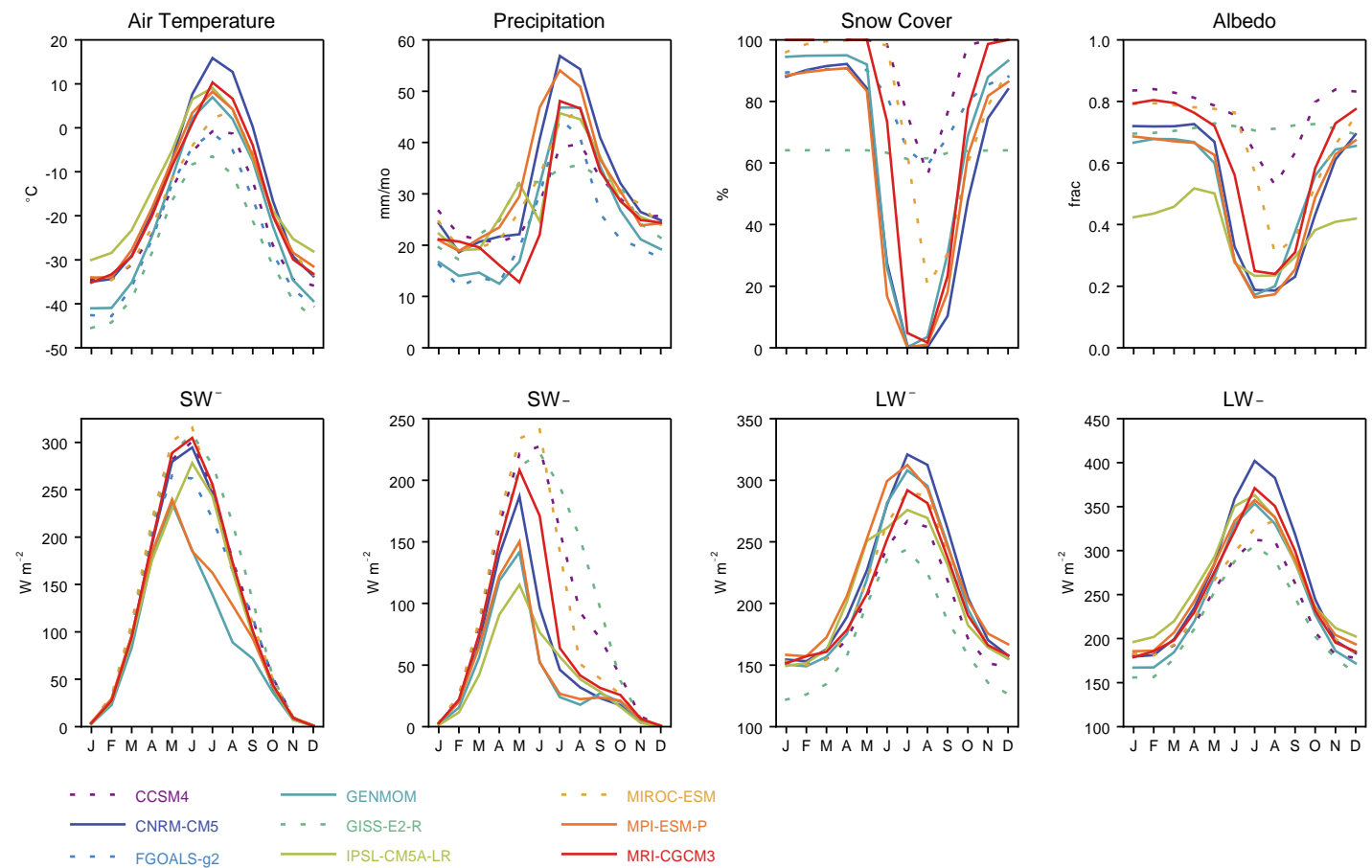

Figure 11: Climatology of Beringia for the nine PMIP3 models. Dashed lines represent models that are ice covered in Beringia using CISM2. Radiations fields are shown for surface shortwave downwelling (SW $\downarrow$ ), shortwave upwelling (SW $\uparrow$ ), longwave downwelling (LW $\downarrow)$, and longwave upwelling (LW $\uparrow$ ) fluxes (top row). Visible band albedo is calculated as shortwave upward radiation divided by shortwave downward radiation (SW / SW $\downarrow)$ at the surface. Data are shown as available at the time of writing. 